\title{
Bactericidal Dendritic Polycation Cloaked with Stealth Material via Lipase-Sensitive Intersegment Acquires Neutral Surface Charge without Losing Membrane-Disruptive Activity
}

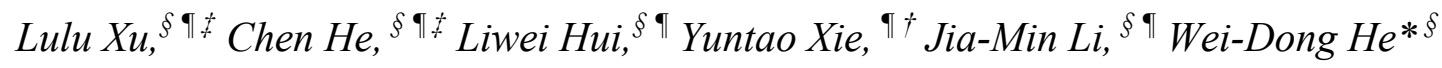

${ }^{\top}$ Lihua Yang*\$ฯ $†$

${ }^{\S}$ CAS Key Laboratory of Soft Matter Chemistry, ${ }^{\natural}$ School of Chemistry and Materials

Science, ${ }^{\dagger}$ CAS Key Laboratory of Materials for Energy Conversion, University of

Science and Technology of China, Hefei, Anhui 230026 China

\# These authors contributed equally.

* Corresponding authors: (L. Y.) lhyang@ustc.edu.cn; (W.-D. H.)wdhe@ustc.edu.cn 


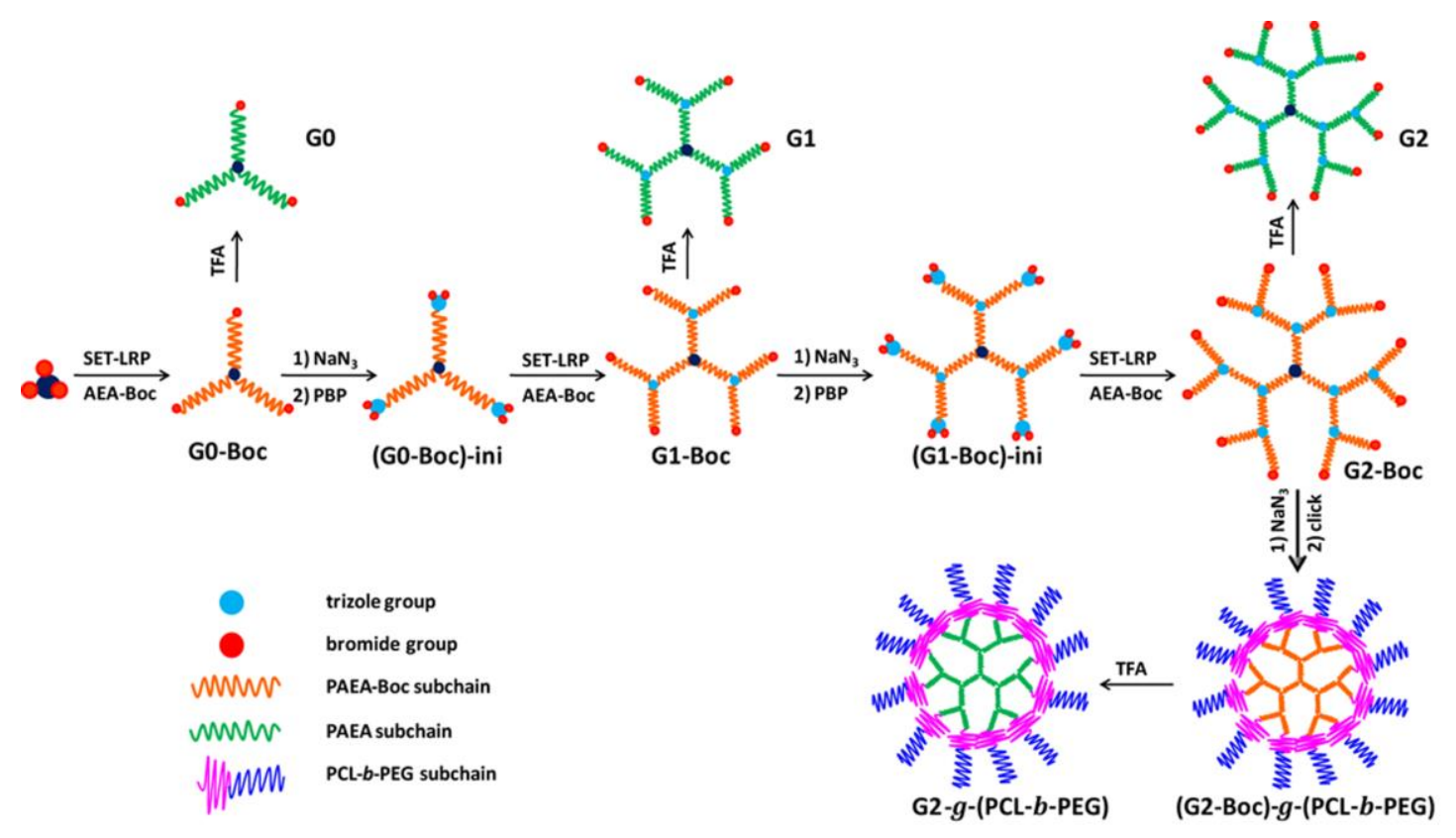

Scheme S1. Schematic illustration of the synthesis route for G2, the second generation of long-chain dendritic poly(ethylamino acrylate), and G2-g-(PCL-b-PEG), the product of coating G2 with PEG via the bacterial lipase-sensitive PCL.

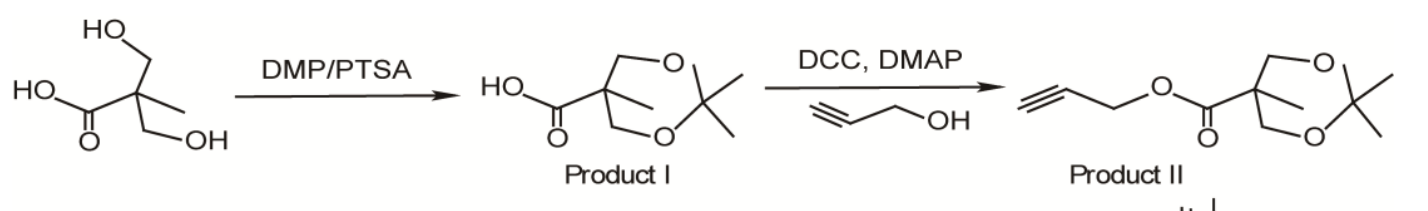<smiles>CC(C)C#CCOC(=O)C(COC(=O)OCC(C)(C)Br)(COC(=O)C(C)(C)C)COC(=O)C(C)(C)Br</smiles><smiles>C#CCOC(=O)C(CO)(CO)CO</smiles>

Scheme S2. Synthesis route for the propargyl

2,2-bis(2'-bromo-2'-methylpropanoyloxy)methyl propionate (PBP). 


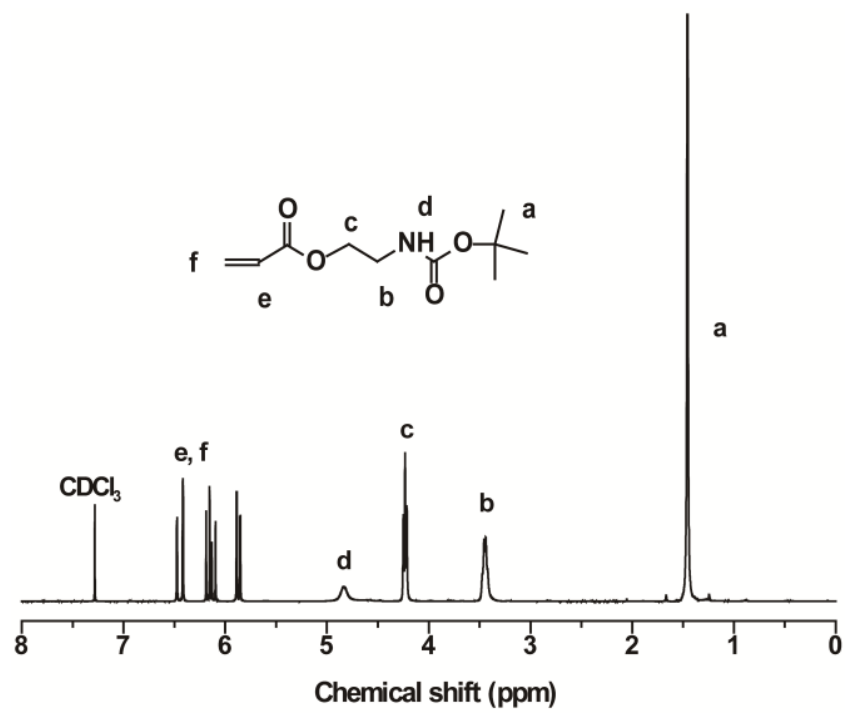

Figure S1. The ${ }^{1} \mathrm{H}$ NMR spectrum of the Boc-protected AEA monomer (i.e., AEA-Boc).

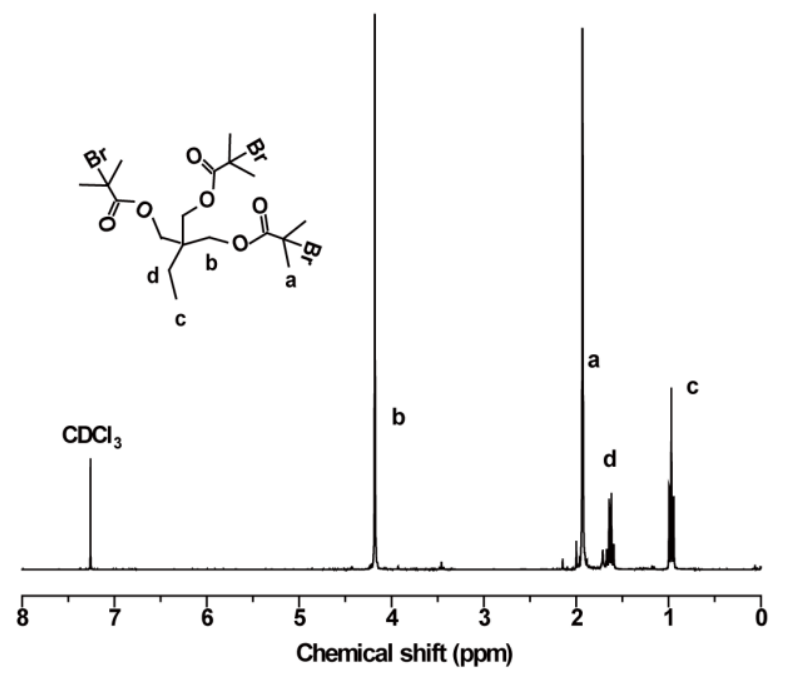

Figure S2. $\quad$ The ${ }^{1} \mathrm{H} \quad$ NMR $\quad$ spectrum of the 1,1,1-Tri(2'-bromo-2'-methylpropionyloxymethyl)propane (TBMP). 

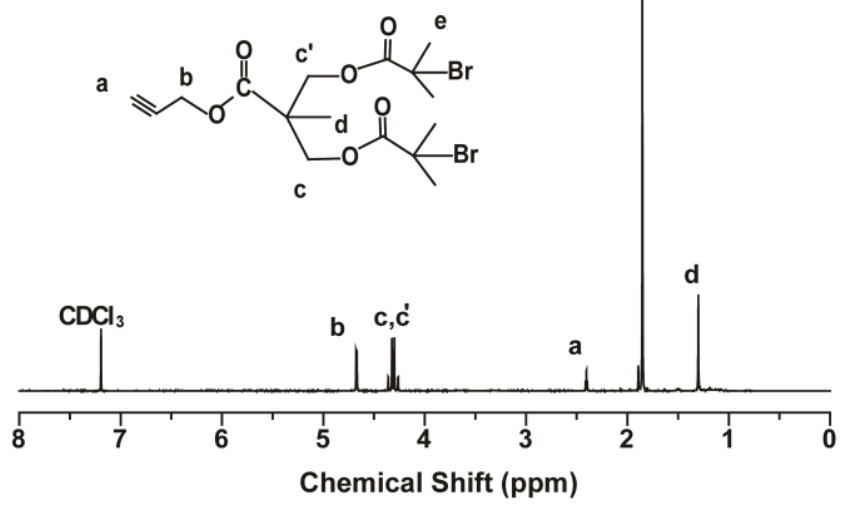

Figure S3. The ${ }^{1} \mathrm{H} \quad$ NMR $\quad$ spectrum of the propargyl 2,2-bis(2'-bromo-2'-methylpropanoyloxy)methyl propionate (PBP).

a)

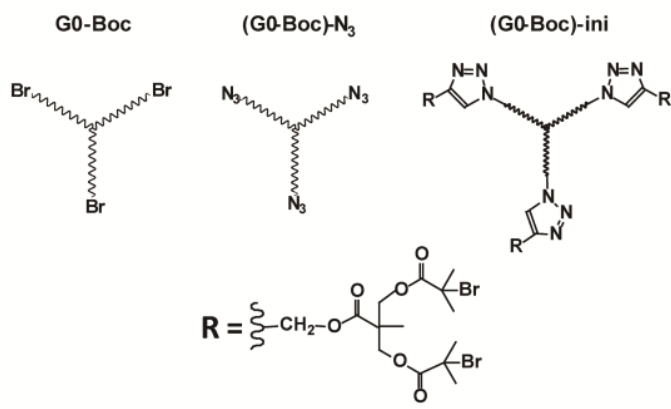

G1-Boc

(G1-Boc)- $\mathrm{N}_{3}$

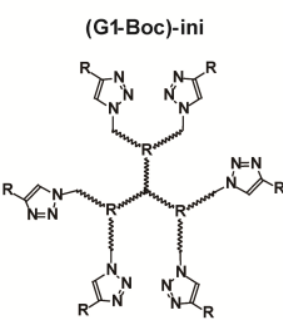

b)
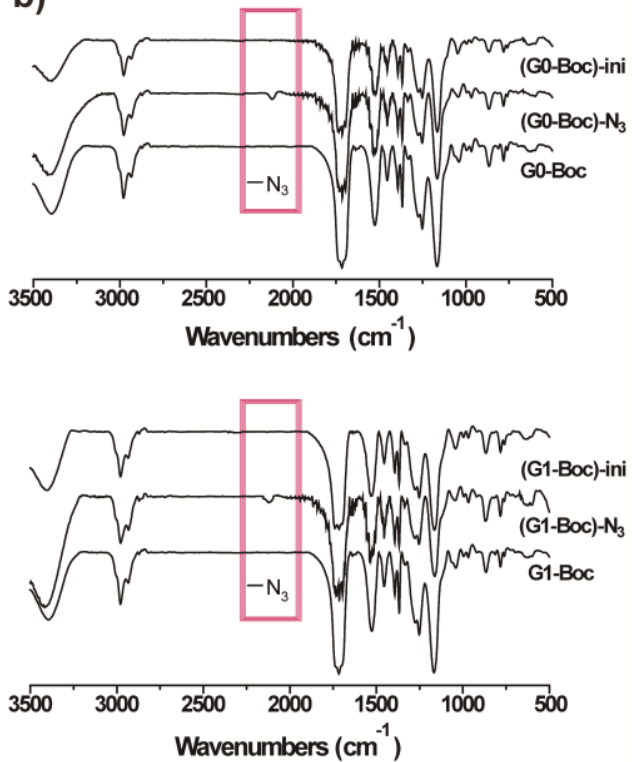

Figure S4. (a) Schematic illustrations on the structures of (top) G0-Boc, (G0-Boc)- $\mathrm{N}_{3}$, and (G0-Boc)-ini, as well as (bottom) G1-Boc, (G1-Boc)- $\mathrm{N}_{3}$, and (G1-Boc)-ini. (b) FT-IR spectra of (top) G0-Boc, (G0-Boc)-N $\mathrm{N}_{3}$, and (G0-Boc)-ini, as well as (bottom) G1-Boc, (G1-Boc)- $\mathrm{N}_{3}$, and (G1-Boc)-ini. 
a)

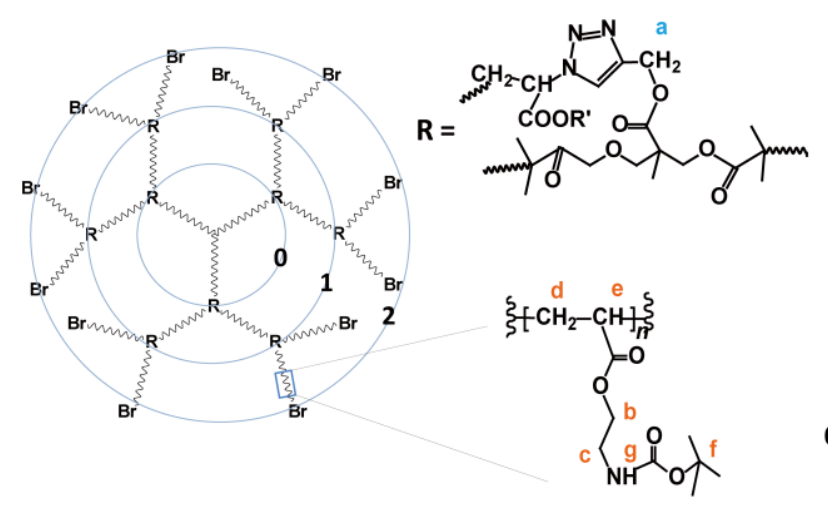

b)

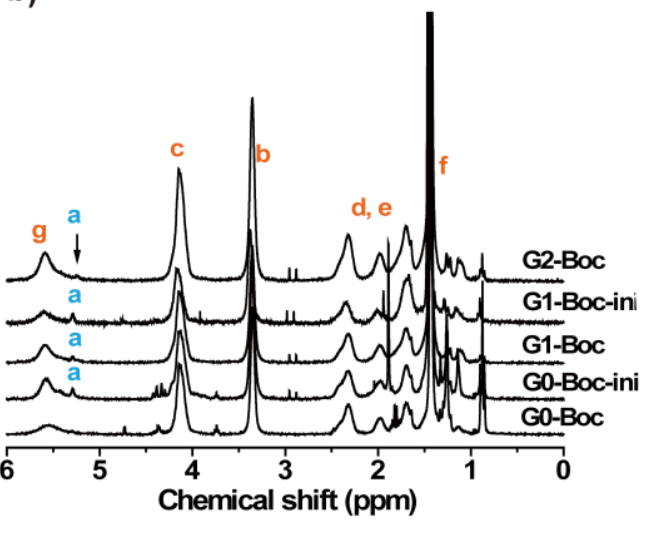

Figure S5. (a) Structures and (b) ${ }^{1} \mathrm{H}$ NMR spectra of G0-Boc, (G0-Boc)-ini, and G1-Boc, (G1-Boc)-ini, and G2-Boc.

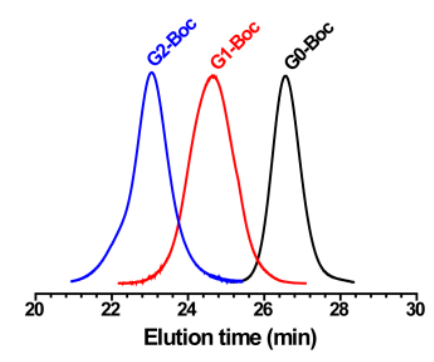

Figure S6. GPC traces with an RI detector of G0-Boc, G1-Boc, and G2-Boc.

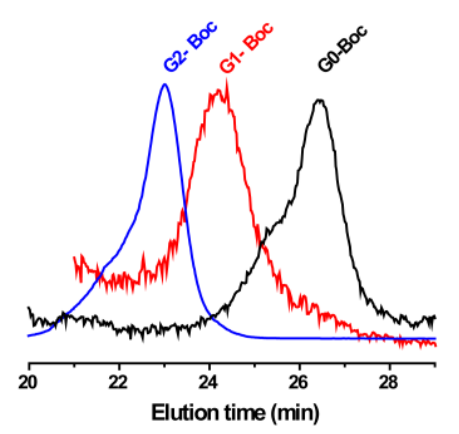

Figure S7. GPC traces with a MALLS detector of G0-Boc, G1-Boc, and G2-Boc. 
a)

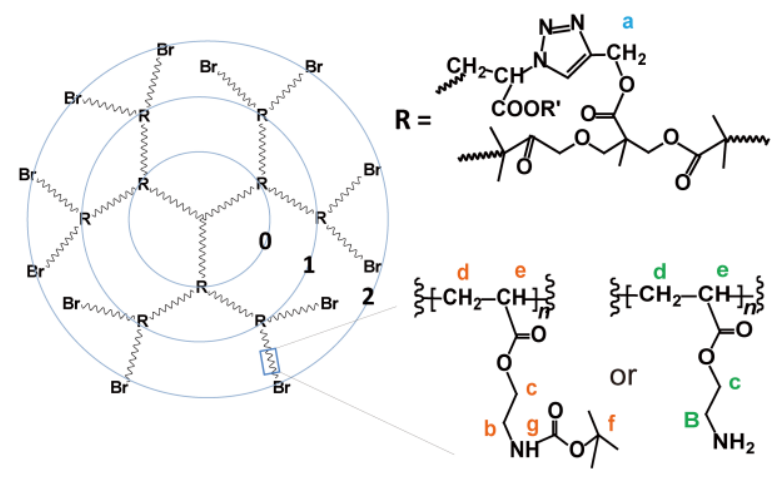

b)

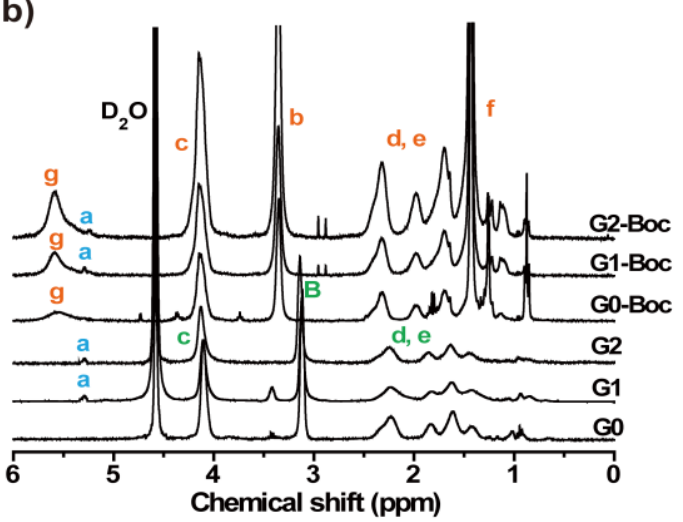

Figure S8. (a) Structures and (b) ${ }^{1} \mathrm{H}$ NMR spectra of G0, G1, G2, as well as the corresponding Boc-protected precursor dendrimers, G0-Boc, G1-Boc, and G2-Boc.

a)

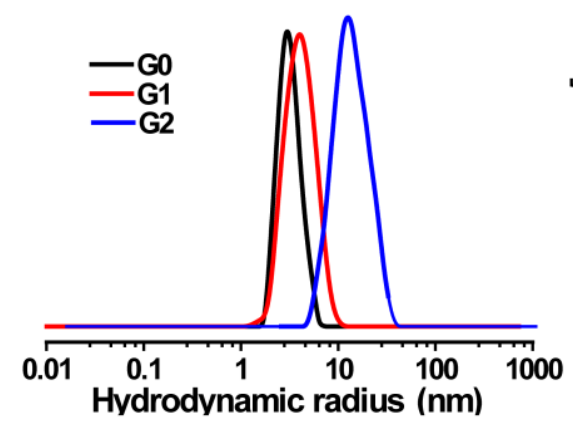

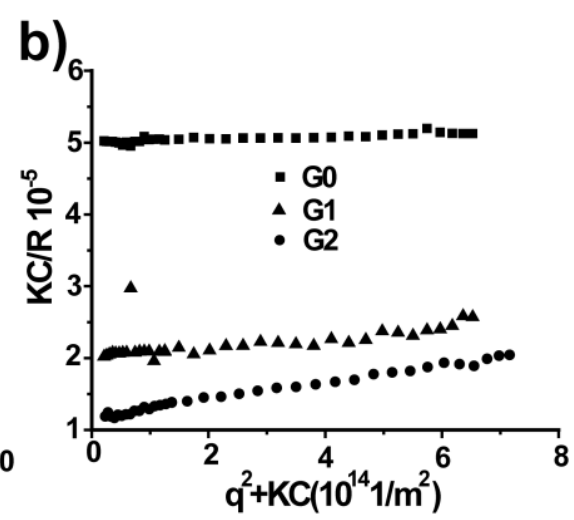

Figure S9. (a) The distributions of hydrodynamic radius $\left(R_{\mathrm{h}}\right)$ of G2, G1, and G0 measured with dynamic laser light scattering; (b) Zimm plots of G2, G1, and G0 measured with static laser light scattering.

Table S1. Yields of the intermediate products during the synthesis process of G2-Boc.

$\begin{array}{lccccccc}\text { Molecule } & \text { G0-Bo } & (G 0-B 0 c)-N_{3} & (G 0-B o c)-i n i & \text { G1-Bo } & (G 1-B o c)-N_{3} & (G 1-B o c)-i n i & \text { G2-Boc } \\ \text { Yield (\%) } & 40 & 67 & 70 & 36 & 69 & 78 & 44\end{array}$


Table S2. The hydrodynamic radius $\left(<R_{\mathrm{h}}>\right)$, gyration radius $\left(<R_{\mathrm{g}}>\right)$, and the molecular conformation of $\mathrm{Gn}(\mathrm{n}=\mathbf{0}, 1,2)$ as indicated by $\left\langle\boldsymbol{R}_{\mathrm{g}}>\mid<\boldsymbol{R}_{\mathrm{h}}\right\rangle$.

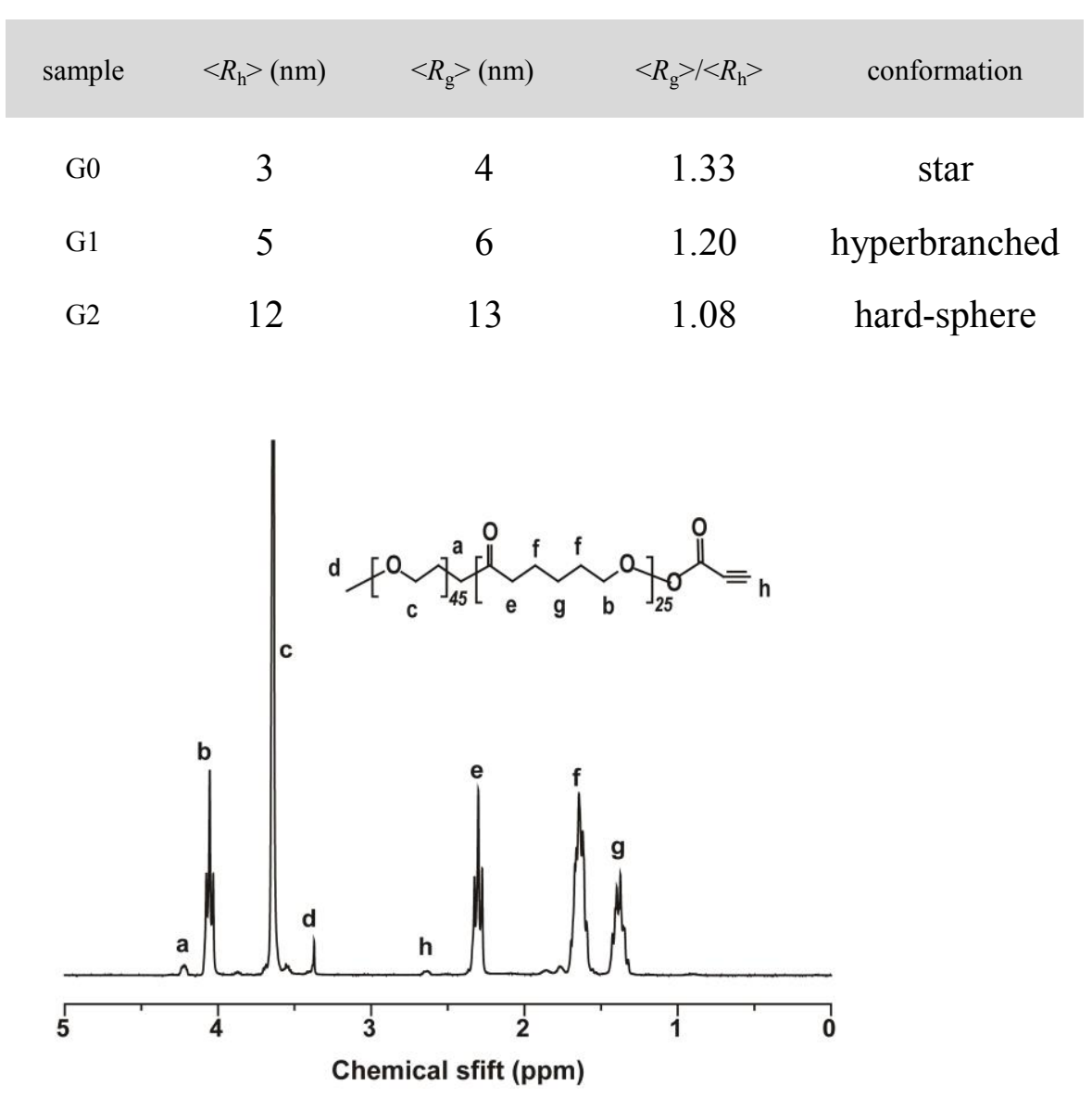

Figure S10. The ${ }^{1} \mathrm{H}$ NMR spectrum of the alkynyl-(PCL- $b$-PEG). 

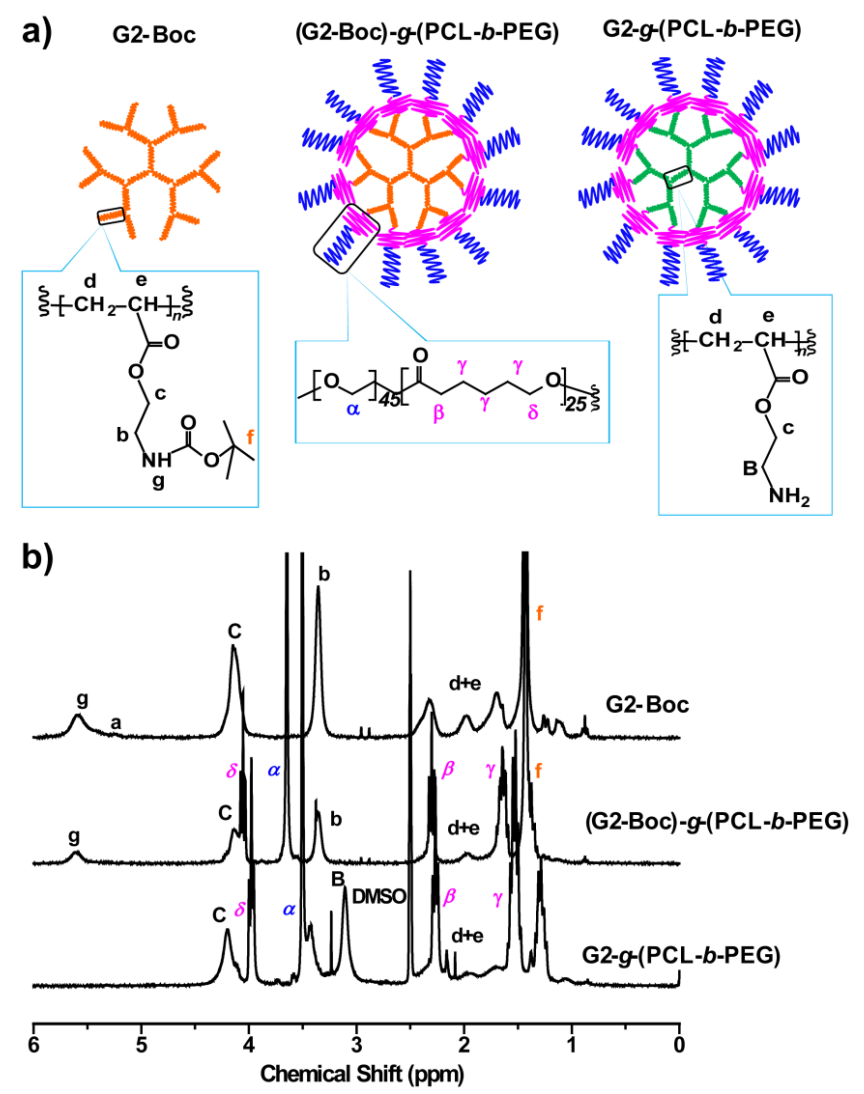

Figure S11. (a) Structures and (b) ${ }^{1} \mathrm{H}$ NMR spectra of G2-g-(PCL-b-PEG), (G2-Boc)-g-(PCL-b-PEG), and G2-Boc.

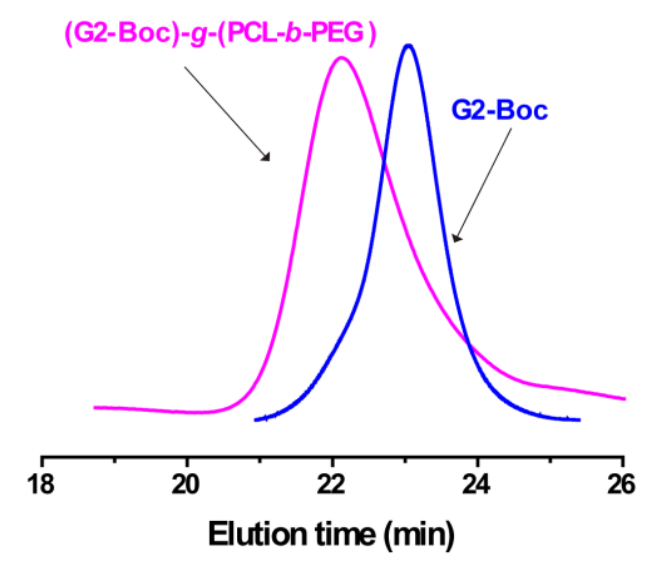

Figure S12. GPC trace with an RI detector of (G2-Boc)-g-(PCL- $b-\mathrm{PEG})$. That of G2-Boc is included as a reference. 
Table S3. The Average Molecular Weights ${ }^{1}$, Polydispersity Indexes (PDI), Average Numbers of the $\mathrm{N}^{\text {th }}$-Generation Arms (f), and Average Lengths of $\mathrm{n}^{\text {th }}$-Generation Arms of the As-Prepared Boc-protected Precursor Dendrimers

\begin{tabular}{|c|c|c|c|c|c|c|c|c|}
\hline & \multicolumn{4}{|c|}{ Molecular weight (Da) } & \multicolumn{4}{|c|}{ length of arms } \\
\hline & $M_{\mathrm{n}, \mathrm{GPC}-\mathrm{I}}$ & $\mathbf{M}_{\mathrm{w}, \mathrm{GPC}-\mathrm{I}}$ & $M_{\mathrm{n}, \mathrm{NMR}}{ }^{\mathrm{a}}$ & $\boldsymbol{M}_{\mathrm{w}, \text { GPC-MALLS }}$ & $P D I$ & $f^{\mathrm{b}}$ & $L_{a r m}^{c}$ & $D_{\text {arm }}{ }^{d}$ \\
\hline G0-Boc & 7300 & 7700 & 8800 & 9000 & 1.07 & 2.9 & 14 & 14 \\
\hline G1-Boc & 21000 & 23000 & 26000 & 27000 & 1.10 & 5.6 & 13 & 14 \\
\hline G2-Boc & 53000 & 62000 & 60000 & 65000 & 1.17 & - & 10 & 15 \\
\hline (G2-Boc)-g-(PCL-b-PEG) & 98000 & 131000 & 108000 & - & 1.34 & - & - & - \\
\hline
\end{tabular}

${ }^{\mathrm{a}}$ Average molecular weight calculated based on ${ }^{1} \mathrm{H}$ NMR spectra of the Boc-protected precursor copolymers. ${ }^{\mathrm{b}}$ Number of the $n^{\text {th }}$-generation arms per $l c d$-PAEA-Boc molecule, $f_{\mathrm{n}}$, calculated based on ${ }^{1} \mathrm{H}$ NMR spectrum of Gn-Boc and GPC trace. Number-averaged chain length of the $n^{\text {th }}$-generation arms calculated based on ${ }^{1} \mathrm{H}$ NMR spectrum of Gn-Boc. ${ }^{\mathrm{d}}$ Weight-averaged chain length of the $n^{\text {th }}$-generation arms calculated based on based on the GPC analysis with a MALLS detector.

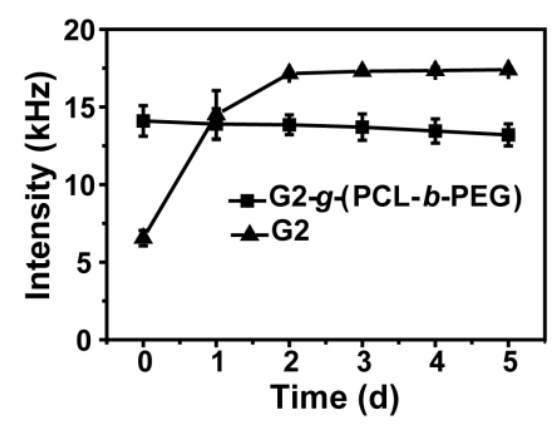

Figure S13. Intensities of dynamic light scattering for G2-g-(PCL- $b$-PEG) in HEPES buffer supplemented with FBS (HEPES/FBS $=50 / 50$, v/v) over a span of 5 days. Those of G2 in similar assay are included as a reference. Data points are reported as mean \pm standard deviation. The reported results are averages of two independent assays. 


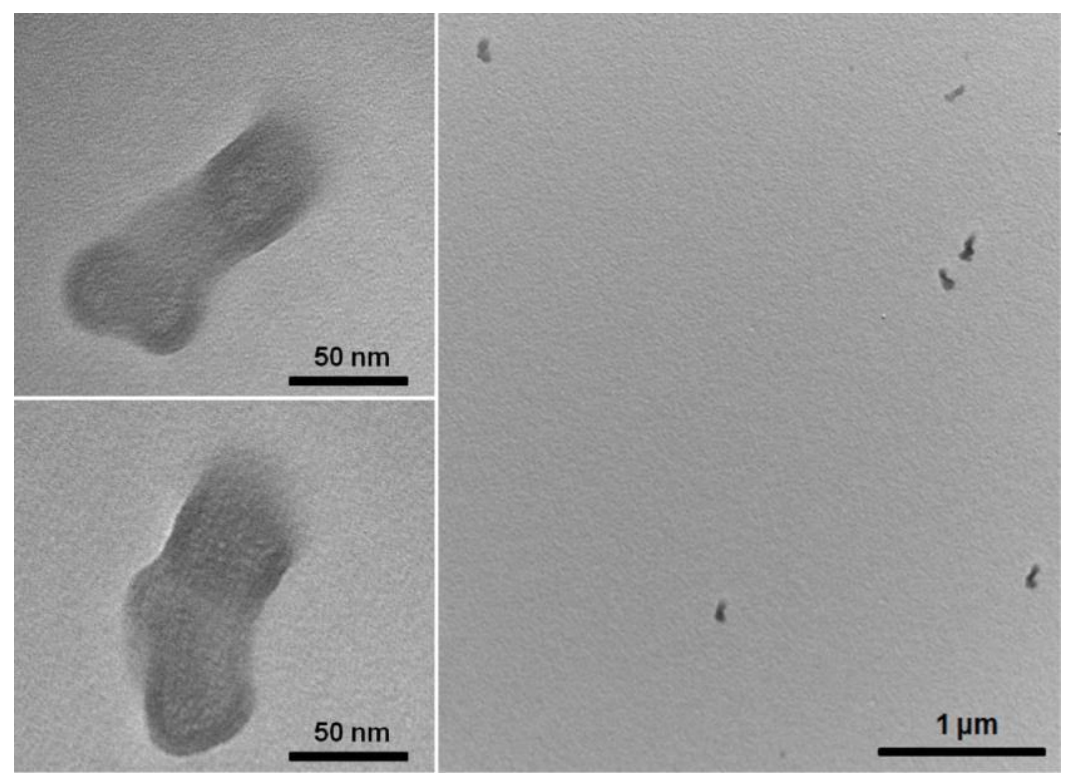

Figure S14. Transmission electron microscopy images of G2-g-(PCL- $b$-PEG).

a)

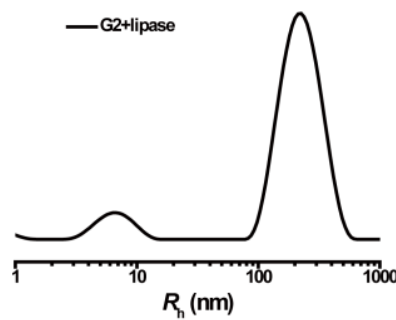

c)

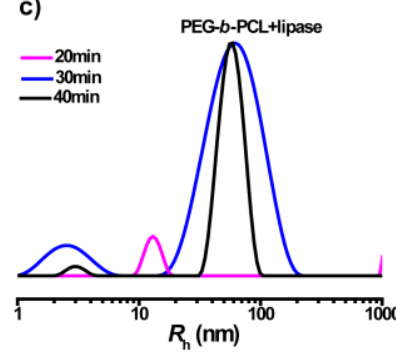

e)

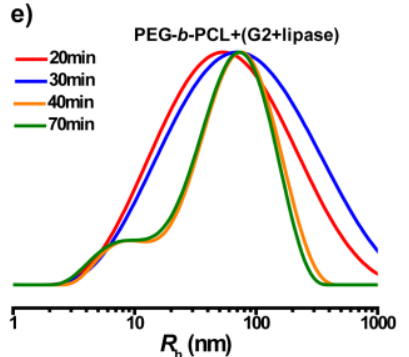

b)

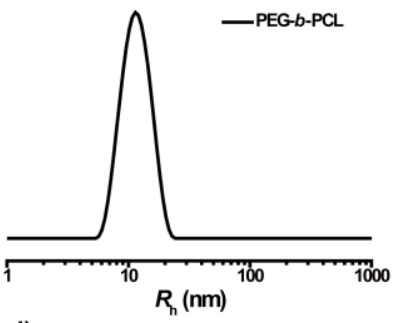

d)

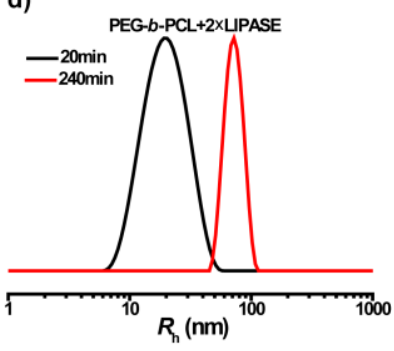

Figure S15. Dynamic laser light scattering characterizations. (a) Distribution of 
hydrodynamic radius $\left(R_{\mathrm{h}}\right)$ for $\mathrm{G} 2(1 \mathrm{mg} / \mathrm{mL})$ after pretreatment via co-culture with lipase (lipase/G2 mass ratio of 5\%) in HEPES buffer for a few hours. (b) Distribution of hydrodynamic radius $\left(R_{\mathrm{h}}\right)$ of PCL- $b$-PEG micelle $(1 \mathrm{mg} / \mathrm{mL})$. (c-d) Distributions of hydrodynamic radius $\left(R_{\mathrm{h}}\right)$ for PCL- $b$-PEG micelle $(0.5 \mathrm{mg} / \mathrm{mL})$ in HEPES buffer at different time-points after addition of bacterial lipase at (c) mass ratio lipase $/ \mathrm{PCL}-b-\mathrm{PEG}=5 \%$ and (d) lipase $/ \mathrm{PCL}-b-\mathrm{PEG}=10 \%$. (e) Distributions of hydrodynamic radius $\left(R_{\mathrm{h}}\right)$ for PCL- $b$-PEG micelle $(0.5 \mathrm{mg} / \mathrm{mL})$ in HEPES buffer at different time-points after addition of bacterial lipase (mass ratio lipase/G2 = lipase/ PCL- $b-\mathrm{PEG}=5 \%)$ which is pretreated via co-culture with $\mathrm{G} 2(0.5 \mathrm{mg} / \mathrm{mL})$ for a few hours.

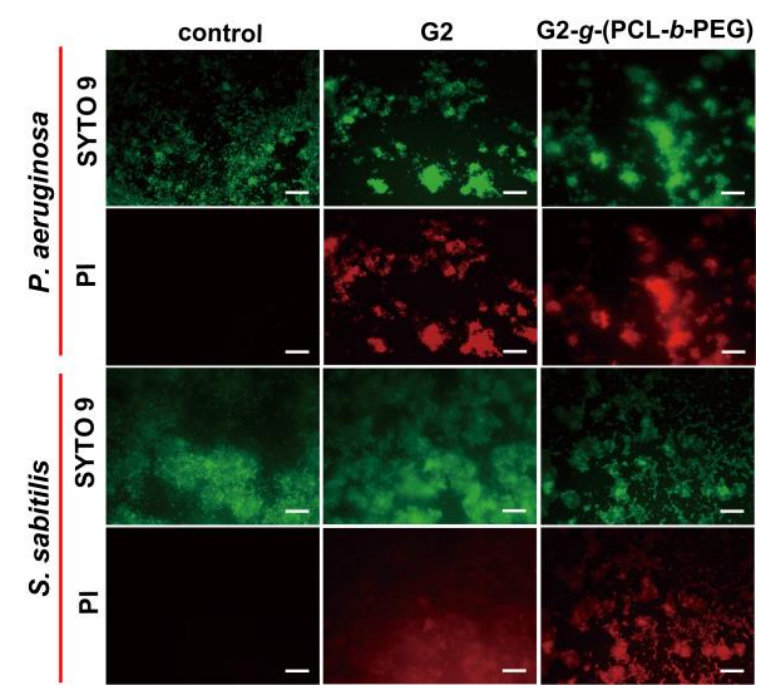

Figure S16. Fluorescence microscopy images of bacterial strains treated with and without a nanoparticle and subsequently stained briefly (15 min) with SYTO-9 (green) and PI (red). The treatment was carried out with $64 \mu \mathrm{g} / \mathrm{mL}$ of either $\mathrm{G} 2$ or G2-g-(PCL- $b$-PEG) for $3 \mathrm{~h}$ in HEPES buffer (10 mM HEPES, $150 \mathrm{mM} \mathrm{NaCl}, \mathrm{pH}$ 
7.4). Controls are those assayed in comparable ways but without addition of dendrimer. Scale bar $=20 \mu \mathrm{m}$.

a)

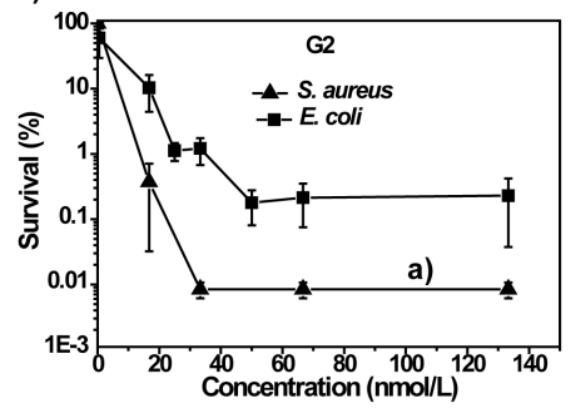

b)

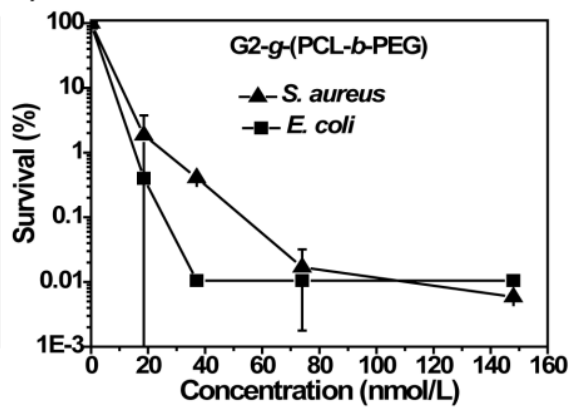

Figure S17. Killing assays show that G2 (a) and G2-g-(PCL- $b$-PEG) (b) is active against both E. coli and $S$. aureus, the widely-used representative Gram-negative and -positive bacteria, respectively. Data points are reported as mean \pm standard deviation. 


\section{ADDITIONAL RESULTS AND DISCUSSION}

\section{Synthesis of G2-Boc}

G2-Boc, the Boc-protected precursor polymer of the long-chain dendritic $(l c d)$ polycation core, was synthesized by divergent synthetic strategy via single-electron-transfer living radical polymerization (SET-LRP) of t-butyloxycarbonyl-aminoethyl acrylate (Boc-AEA) (Scheme S1). (1): G0-Boc, the tri-arm star polymer PAEA-Boc, was synthesized from the tri-functional initiator of TBMP via SET-LRP. (2): Using the resulting G0-Boc, G1-Boc the Boc-protected precursor polymer of the first generation of $l c d$-PAEA was synthesized by converting the terminal bromo groups of G0-Boc into azido groups with $\mathrm{NaN}_{3}$ in $\mathrm{DMF}$ (which yielded (G0-Boc)- $\mathrm{N}_{3}$ ) and then introducing the bifunctional initiation PBP molecules via alkynyl-azido click reaction (which yielded (G0-Boc)-ini), followed by SET-LRP of AEA-Boc with (G0-Boc)-ini as the initiator. (3): Using the resulting G1-Boc, G2-Boc the Boc-protected precursor polymer of the second generation of lcd-PAEA was synthesized by converting the terminal bromo groups of G1-Boc into azido groups (which yielded $\left.(\mathrm{G} 1-\mathrm{Boc})-\mathrm{N}_{3}\right)$ and then introducing PBP residues via alkynyl-azido click reaction (which yielded (G1-Boc)-ini) followed by SET-LRP of AEA-Boc with (G1-Boc)-ini as the initiator.

After TFA-deprotection, the as-synthesized G0-Boc, G1-Boc, and G2-Boc yielded G0, G1, and G2, respectively; G0 denotes the tri-arm star PAEA polymer, while G1 and G2 denotes the first and second generations of $l c d$-PAEA, respectively. 


\section{Structural Characterizations on G2-Boc and Important Intermediate}

\section{Products}

Figure S4 shows the structures and FT-IR spectra of important intermediate products in the synthesis of G2-Boc. Comparisons on the FT-IR spectra of G0-Boc, (G0-Boc)- $\mathrm{N}_{3}$, and (G0-Boc)-ini reveal that, compared to $\mathrm{G} 0$-Boc, (G0-Boc)- $\mathrm{N}_{3}$ exhibits an extra absorption peak at $2,104 \mathrm{~cm}^{-1}$ which is characteristic of the stretching absorption of azido group $\left(-\mathrm{N}_{3}\right)$, indicative of successful conversion of the terminal bromo groups in $\mathrm{G} 0-\mathrm{Boc}$ into azido groups expected in $(\mathrm{G} 0-\mathrm{Boc})-\mathrm{N}_{3}$; this same absorption peak of $-\mathrm{N}_{3}$ group disappears in the FT-IR spectrum of (G0-Boc)-ini, indicative of azido group depletion, suggesting successful proceeding of the expected alkynyl-azido click reaction. Similar results are observed when comparing the FT-IR spectra of G1-Boc, (G1-Boc)-N ${ }_{3}$, and (G1-Boc)-ini.

Figure S5 shows the structures and ${ }^{1} \mathrm{H}-\mathrm{NMR}$ spectra of G2-Boc and the important intermediate products in its synthesis G0-Boc, (G0-Boc)-ini, G1-Boc, and (G1-Boc)-ini. Compared to the ${ }^{1} \mathrm{H}-\mathrm{NMR}$ spectrum of G0-Boc, that of (G0-Boc)-ini shows an extra signal peak $\left(\mathrm{H}_{\mathrm{a}}, \delta\right.$ of 5.29) that can be indexed to the methylene protons between trizole group and ester group, indicative of successful introduction of the bifunctional initiation PBP molecules via alkynyl-azido click reaction. As expected, this $\mathrm{H}_{\mathrm{a}}$ signal peak is observed consistently with G1-Boc, (G1-Boc)-ini, and G2-Boc. 
GPC traces with an RI detector (Figure S6) reveal that, for G0-Boc, G1-Boc and G2-Boc, all the GPC traces are unimodal and symmetrical and the apparent molecular weight increases appreciably from G0-Boc over G1-Boc to G2-Boc.

GPC analysis with a multi-angle laser light scattering (MALLS) detector (Figure S7) reveals that absolute weight-averaged molecular weight of the $l c d$-(PAEA-Boc) increases appreciably from G0-Boc over G1-Boc to G2-Boc.

\section{Calculations on the Average Molecular Weights based on ${ }^{1}$ H NMR Spectra}

For G0-Boc, the number-averaged molecular weight $\left(M_{\mathrm{n}, \mathrm{NMR}}\right)$ (Table $\mathrm{S} 3$ ) is calculated using the following function:

$$
M_{\mathrm{n}, \mathrm{NMR}}=3 M_{\mathrm{AEA}-\mathrm{Boc}} \times A_{\mathrm{c}} / A_{\mathrm{a}}
$$

where $M_{\mathrm{AEA}-\mathrm{BOC}}$ is molecular weight of AEA-Boc unit, and $A_{\mathrm{a}}$ and $A_{\mathrm{c}}$ are based on the integral heights of $\mathrm{H}_{\mathrm{a}}$ and $\mathrm{H}_{\mathrm{c}}$, respectively, in its ${ }^{1} \mathrm{H}$ NMR spectrum.

For G1-Boc and G2-Boc, the number-averaged molecular weights $\left(M_{\mathrm{n}, \mathrm{NMR}}\right)$ (Table S3) are calculated using the following equation:

$$
M_{\mathrm{n}, \mathrm{NMR}}=9 M_{\mathrm{AEA}-\mathrm{Boc}} \times A_{\mathrm{c}} / A_{\mathrm{a}}
$$

where $M_{\mathrm{AEA}-\mathrm{BOC}}$ is molecular weight of AEA-Boc unit, and $A_{\mathrm{a}}$ and $A_{\mathrm{c}}$ are based on the integral heights of $\mathrm{H}_{\mathrm{a}}$ and $\mathrm{H}_{\mathrm{c}}$, respectively, in the corresponding ${ }^{1} \mathrm{H}$ NMR spectrum.

\section{Calculations on the Average Numbers of $n^{\text {th }}$-Generation Arms for G1-Boc and G2-Boc}

The number of the $n^{\text {th }}$-generation arms per $l c d$-(PAEA-Boc) molecule, $f_{\mathrm{n}}$, was determined by calculating the number of PBP residues per $\left(\mathrm{G}_{\mathrm{n}-1}\right.$-Boc)-ini 
macromolecule. Specifically, for G1-Boc, the number of the $1^{\text {st }}$-generation arms per G1-Boc is determined by calculating the number of PBP residues per (G0-Boc)-ini macromolecule, using the following equation:

$$
f_{0}=\frac{A_{\mathrm{a}}}{A_{c}} \times \frac{M_{\mathrm{W}, \mathrm{MALLS}} / \mathrm{PDI}}{M_{\mathrm{AEA}-\mathrm{Boc}}}
$$

where $M_{\mathrm{AEA}-\mathrm{Boc}}$ is molecular weight of AEA-Boc monomer, $M_{\mathrm{w}, \text { GPC-MALLS }}$ is the molecular weight of G0-Boc determined using GPC with a MALLS detector, PDI is the polydispersity index of G0-Boc determined using GPC with an RI detector, and $A_{a}$ and $A_{c}$ are the integral heights of signal peaks $H_{a}$ and $H_{c}$, respectively, in the ${ }^{1} \mathrm{H}$ NMR spectrum of G0-Boc. The value of $f_{0}$ is calculated to be 2.9 , indicative of successful introduction of 3 PBP molecules into G0-Boc, suggesting that there are 6 $1^{\text {st }}$-generation arms on average per G1-Boc.

Similarly, the number of the $2^{\text {nd }}$-generation arms per G2-Boc is determined by calculating the number of PBP residues on the $1^{\text {st }}$-generation arms in (G1-Boc)-ini macromolecule, using the following equation:

$$
f_{1}=\frac{A_{\mathrm{a}}}{A_{c}} \times \frac{\left(M_{\mathrm{W}, \mathrm{MALLS}} / \mathrm{PDI}\right)_{1}}{M_{\mathrm{AEA}-\mathrm{Boc}}}-f_{0}
$$

where $M_{\mathrm{AEA}-\mathrm{BOC}}$ is molecular weight of AEA-Boc monomer, $M_{\mathrm{w}}$ GPC-MALLS is the molecular weight of G1-Boc determined using GPC with a MALLS detector, PDI is the polydispersity index of G1-Boc determined using GPC with an RI detector, and $A_{a}$ and $A_{c}$ are the integral heights of signal peaks $H_{a}$ and $H_{c}$, respectively, in the ${ }^{1} H$ NMR spectrum of G1-Boc. The value of $f_{1}$ is calculated to be 5.6, indicative of 
successful introduction of 6 PBP molecules into the $1^{s t}$-generation arms in G1-Boc, suggesting that there are $122^{\text {nd }}$-generation arms on average per G2-Boc.

\section{Calculations on the Average Lengths of $\boldsymbol{n}^{\text {th }}$-Generation Arms for G0-Boc, G1-Boc, and G2-Boc}

The number-averaged chain length of the $n^{\text {th }}$-generation arms in a Gn-Boc, $L_{\text {arm,n }}$, (Table S3) is determined based on ${ }^{1} \mathrm{H}$ NMR spectrum of Gn-Boc. Specifically, for G0-Boc, its number-averaged chain length of the $0^{\text {th }}$-generation arms, $L_{\text {arm, }} 0$, is calculated using the following equation:

$$
L_{\mathrm{arm}, 0}=A_{c} / A_{\mathrm{a}}
$$

where $A_{a}$ and $A_{c}$ are the integral heights of signal peaks $H_{a}$ and $H_{c}$, respectively, in the ${ }^{1} \mathrm{H}$ NMR spectrum of G0-Boc.

For G1-Boc, its number-averaged chain length of the $1^{s t}$-generation arms, $L_{\mathrm{arm}, 1}$, is calculated using the following equation:

$$
L_{\mathrm{arm}, 1}=\left(9 A_{c} / A_{\mathrm{a}}-3 \times L_{\mathrm{arm}, 0}\right) / 6
$$

where $L_{\text {arm, } 0}$ is the number-averaged chain length of the $0^{\text {th }}$-generation arms of G0-Boc, and $A_{a}$ and $A_{c}$ are the integral heights of signal peaks $H_{a}$ and $H_{c}$, respectively, in the ${ }^{1} \mathrm{H}$ NMR spectrum of G1-Boc.

For G2-Boc, its number-averaged chain length of the $2^{\text {nd }}$-generation arms, $L_{\mathrm{arm}, 2}$, is calculated using the following equation:

$$
L_{\mathrm{arm}, 2}=\left(9 A_{c} / A_{\mathrm{a}}-3 \times L_{\mathrm{arm}, 0}-6 \times L_{\mathrm{arm}, 1}\right) / 12
$$

Where $L_{\mathrm{arm}, 0}$ is the number-averaged chain length of the $0^{\text {th }}$-generation arms of G0-Boc, $L_{\text {arm, } 1}$ is the number-averaged chain length of the $1^{s t}$-generation arms of 
G1-Boc, and $A_{a}$ and $A_{c}$ are the integral heights of signal peaks $H_{a}$ and $H_{c}$, respectively, in the ${ }^{1} \mathrm{H}$ NMR spectrum of G2-Boc.

On the other hand, the weight-averaged chain length of the $n^{\text {th }}$-generation arms in a Gn-Boc, $D_{\text {arm,n }}$, is determined based on the GPC analysis with a MALLS detector. Specifically, for G0-Boc, its weight-averaged chain length of the $0^{\text {th }}$-generation arms, $D_{\text {arm, } 0}$, is calculated using the following equation:

$$
D_{\text {arm }, 0}=M_{\mathrm{w}_{0}, \mathrm{MALLS}} / 3 M_{\mathrm{AEA}-\mathrm{Boc}}
$$

where $M_{\mathrm{AEA}-\mathrm{Boc}}$ is molecular weight of AEA-Boc monomer, and $M_{\mathrm{w} 0 \text {, GPC-MALLS }}$ is the molecular weight of G0-Boc determined using GPC with a MALLS detector.

For G1-Boc, its weight-averaged chain length of the $1^{\text {st }}$-generation arms, $D_{\text {arm, } 1}$, is calculated using the following equation:

$$
D_{\mathrm{arm}, 1}=\left(M_{\mathrm{w}_{1}, \mathrm{MALLS}}-M_{\mathrm{w}_{0}, \mathrm{MALLS}}\right) / 6 M_{\mathrm{AEA}-\mathrm{Boc}}
$$

where $M_{\mathrm{AEA}-\mathrm{Boc}}$ is molecular weight of AEA-Boc monomer, and $M_{\mathrm{w} 1, \text { GPC-MALLS }}$ and $M_{\mathrm{w} 0 \text {, GPC-MALLS }}$ are the molecular weights of G1-Boc and G0-Boc, respectively, determined using GPC with a MALLS detector.

For G2-Boc, its weight-averaged chain length of the $2^{\text {nd }}$-generation arms, $D_{\text {arm, } 2 \text {, is }}$ calculated using the following equation:

$$
D_{\mathrm{arm}, 2}=\left(M_{\mathrm{W}_{2}, \mathrm{MALLS}}-M_{\mathrm{W}_{1}, \mathrm{MALLS}}\right) / 12 M_{\mathrm{AEA}-\mathrm{Boc}}
$$

where $M_{\mathrm{AEA}-\mathrm{Boc}}$ is molecular weight of AEA-Boc monomer, and $M_{\mathrm{w} 2 \text {, GPC-MALLS }}$ and $M_{\mathrm{w} 1, \text { GPC-MALLS }}$ are the molecular weights of G2-Boc and G1-Boc, respectively, determined using GPC with a MALLS detector. 


\section{Structural Characterizations on G2 and Related Intermediate Products}

G2 is prepared by removing the Boc-groups from G2-Boc with TFA-deprotection process; similarly, G1 and G0 are obtained from G1-Boc and G0-Boc, respectively. , Figure S8 shows the ${ }^{1} \mathrm{H}$ NMR spectra of $\mathrm{Gn}$ and $\mathrm{Gn}-\mathrm{Boc}(\mathrm{n}=0,1,2)$, which confirm the successful removal of Boc-groups with TFA-treatment. Compared to the ${ }^{1} \mathrm{H}$ NMR spectra of G2-Boc, that of $\mathrm{G} 2$ has the $\mathrm{H}_{\mathrm{g}}(\delta 5.59 \mathrm{ppm})$ and $\mathrm{H}_{\mathrm{f}}(\delta 1.43$ ppm)signal peaks disappeared and the signal peak of the methylene protons adjacent to the amine group shift from $\mathrm{H}_{\mathrm{b}}$ to $\mathrm{H}_{\mathrm{B}}$ ( $\delta$ from 3.3 to $3.1 \mathrm{ppm}$ ), indicative of successful removal of Boc-groups after TFA-deprotection. Similar results are observed with G1 versus G1-Boc, and G0 versus G0-Boc.

\section{Characterizations on the Radius of G2 as well as G0 and G1}

Figure S9a shows that the hydrodynamic radius $\left(R_{\mathrm{h}}\right)$ distributions of G0, G1 and G2 in HEPES buffer solution, which are clearly unimodal and narrow and demonstrate a unidirectional increase in hydrodynamic radius $\left(R_{\mathrm{h}}\right)$ from $3 \mathrm{~nm}$ for $\mathrm{G} 0$, over $4 \mathrm{~nm}$ for $\mathrm{G} 1$, to $12 \mathrm{~nm}$ for $\mathrm{G} 2$. Figure $\mathrm{S} 9 \mathrm{~b}$ shows the gyration radius $\left(R_{\mathrm{g}}\right)$ distributions of $\mathrm{G} 0$, G1 and G2, which have gyration radii of 4, 5 and $13 \mathrm{~nm}$, respectively. The resulting $R_{\mathrm{g}} / R_{\mathrm{h}}$ values for these three polymers suggest that all of them may be molecularly dissolved in HEPES buffer solution and, as the generation increases, the molecular conformation changes from star for G0, over hyperbranched for G1, to hard-sphere for G2 (Table S2) ${ }^{2-4}$.

\section{Structural Characterizations on G2-g-(PCL- $b$-PEG)}


Figure S11 shows the ${ }^{1} \mathrm{H}-\mathrm{NMR}$ spectra of (G2-Boc)-g-(PCL- $b$-PEG) in $\mathrm{CDCl}_{3}$ and G2- $g$-(PCL- $b$-PEG) in $\mathrm{d}_{6}$-DMSO, with that of $\mathrm{G} 2-\mathrm{Boc}$ in $\mathrm{CDCl}_{3}$ included as a reference. Compared with the ${ }^{1} \mathrm{H}$ NMR spectrum of G2-Boc, that of (G2-Boc)-g-(PCL-b-PEG) exhibits four extra signal peaks that can be indexed to the methylene protons of PEG $\left(\mathrm{H}_{\alpha}\right)$ and PCL $\left(\mathrm{H}_{\beta}, \mathrm{H}_{\gamma}\right.$ and $\left.\mathrm{H}_{\delta}\right)$, indicating that PCL- $b$-PEG has been successfully grafted onto G2-Boc. Compared to the ${ }^{1} \mathrm{H}$ NMR spectrum of (G2-Boc)-g-(PCL- $b$-PEG), that of G2-g-(PCL- $b$-PEG) has the $\mathrm{H}_{\mathrm{g}}(\delta 5.59 \mathrm{ppm})$ and $\mathrm{H}_{\mathrm{f}}$ ( $\delta 1.43 \mathrm{ppm}$ ) signal peaks disappeared and the signal peak of the methylene protons adjacent to the amine group shift from $\mathrm{H}_{\mathrm{b}}$ to $\mathrm{H}_{\mathrm{B}}$ ( $\delta$ from 3.3 to $3.1 \mathrm{ppm}$ ), indicative of successful removal of Boc-groups after TFA-deprotection.

Combined with the $M_{\mathrm{n}, \mathrm{NMR}}$ values of $\mathrm{G} 2$ and PCL- $b-\mathrm{PEG}$, both of which are calculated based on their ${ }^{1} \mathrm{H}$ NMR spectra, the integral heights of $\mathrm{H}_{\alpha}$ and $\mathrm{H}_{\mathrm{b}}$, in the ${ }^{1} \mathrm{H}$ NMR spectrum of G2-g-(PCL- $b$-PEG) indicate that the number of grafted PCL- $b$-PEG chains per G2 is estimated to be $\sim 12$, suggesting that all the azido groups of G2-Boc underwent click reaction with PCL- $b$-PEG.

GPC traces (Figure S12) shows that (G2-Boc)-g-(PCL-b-PEG) exhibits appreciable increase in apparent molecular weight as compared to G2-Boc while retaining a narrow molecular weight distribution $(\mathrm{PDI}=1.37)$.

9. Responsive Degradation of G2-g-(PCL- $b$-PEG) toward G2 by Bacterial Lipase. PCL undergoes responsive degradation upon exposure to bacterial lipase. ${ }^{5-8}$ To confirm that bacterial lipase degrades PCL intersegment in G2-g-(PCL- $b$-PEG), we monitor the distributions of hydrodynamic radius $\left(R_{\mathrm{h}}\right)$ for G2-g-(PCL- $b$-PEG) in 
HEPES buffer at different time-points after lipase addition (Figure 2e). At 10 min after lipase addition, the distribution of $R_{\mathrm{h}}$ exhibits a single unimodal peak but starts to become broader and smaller $R_{\mathrm{h}}$ than that prior to lipase addition $(\mathrm{t}=0 \mathrm{~min})$. At 20 min after lipase addition, distribution of $R_{\mathrm{h}}$ has an additional broad peak around $\sim 10 \mathrm{~nm}$ which overlaps with the even broader one indexable to G2-g-(PCL- $b$-PEG), indicative of emergence of G2 as a product of lipase-triggered PCL degradation. ${ }^{5-8}$ At 300 min after lipase addition, the distribution of $R_{\mathrm{h}}$ exhibits two well separated peaks, with one around $\sim 10 \mathrm{~nm}$ while another around $\sim 100 \mathrm{~nm}$; after that, both the positions and the relative intensities of these two peaks remain barely changed. 


\section{MATERIALS AND METHODS}

\section{Materials.}

Copper (I) bromide was purchased from Sinopharm (Shanghai, China) and, upon arrival, washed successively with sodium sulfite aqueous solution, hydrogen bromide aqueous solution, glacial acetic acid, and ethyl alcohol (95\%) followed by dehydation under vacuum for overnight, and the resulting white product, purified copper (I) bromide, was used within one month. Isopropanol was purchased from Sinopharm (Shanghai, China) and vacuum distilled prior to use. $\varepsilon$-Caprolactone (Aldrich, Shanghai, China) and toluene (Sinopharm, Shanghai, China) were dried over $\mathrm{CaH} 2$ and vacuum distilled prior to use. Methoxy poly(ethylene glycol) $(\mathrm{Mn}=2000$, PEG-2000) was purchased from Sigma-Aldrich (Shanghai, China) and dried by azeotropic distillation of toluene, precipitated in diethyl ether, and dried under vacuum for overnight. Burkholderiacepacia lipase was purchased from Aldrich (Shanghai, China) and used as supplied without further purification. Dehydrated Mueller-Hinton (MH) medium formulation and Tryptic Soy Broth medium formulation were purchased from Qingdao Hope Bio-Technology (Qingdao, China) and used as supplied to prepare cation-adjusted Mueller-Hinton (caMH) broth and Tryptic Soy broth. Bacterial strains used in this work were purchased from American Type Culture Collection (ATCC) (Virginia, USA). E. coli (ATCC 25922) and P. aeruginosa (ATCC 29853) were used as representatives for Gram-negative bacteria while S. aureus (ATCC 25923) and B. subtilis (ATCC 6051) were used as 
representatives for Gram-positive bacteria. Other reagents were purchased from Sigma-Aldrich, Sinopharm Chemical Reagent and Aladdin.

\section{Synthesis of t-butyloxycarbonyl-aminoethyl acrylate (AEA-Boc).}

AEA-Boc was prepared via a procedure with slight modification ${ }^{9-11}$. Tert-butyl $N$-(2-hydroxyethyl) carbamate was prepared by stirring the mixture of di-tert-butyl dicarbonate $(30.0 \mathrm{~g}, 137.5 \mathrm{mmol})$ and 2-aminoethanol (10.0 g, $164.4 \mathrm{mmol})$ in distilled (DI) water $(250 \mathrm{~mL})$ at room temperature for $7 \mathrm{~h}$. The water phase was subsequently extracted with ethyl acetate and the residual organic phase was washed successively with saturated $\mathrm{NaHCO}_{3}$ aqueous solution and DI water, followed by dehydration with anhydrous $\mathrm{MgSO}_{4}$. After removing the solvent via evaporation at reduced pressure, the residual yieled Boc-2-aminoethanol.

The as-prepared Boc-2-aminoethanol (16.1 g, $100 \mathrm{mmol})$ was dissolved with $\mathrm{CH}_{2} \mathrm{Cl}_{2}(90 \mathrm{~mL})$ followed by addition triethyl amine $(10.2 \mathrm{~g}, 100 \mathrm{mmol})$. The resulting mixture was then cooled with an ice/water bath, followed by slow drop-wise addition of acryloyl chloride (10.9 g, $120 \mathrm{mmol})$ in $\mathrm{CH}_{2} \mathrm{Cl}_{2}(40 \mathrm{~mL})$ (taking approximately $30 \mathrm{~min}$ ). After having been stirred at room temperature for overnight, the resulting mixture was filtered and subsequently washed with DI water $(10 \mathrm{~mL})$ for three times. The residual organic phase was dried with anhydrous $\mathrm{MgSO}_{4}$, subjected to rotary evaporation at reduced pressure, and purified with silica gel-column chromatography with hexane/ethyl acetate $(4: 1, \mathrm{v} / \mathrm{v})$ as the eluant, which yielded AEA-Boc as white crystalline needles. $\quad{ }^{1} \mathrm{H}$ NMR spectrum (AC-250, Bruker) (Figure S1) confirmed the successful preparation of AEA-Boc. ${ }^{1} \mathrm{H}$ NMR $\left(\mathrm{CDCl}_{3}, \mathrm{ppm}\right): \delta$ 
6.45-5.83 ppm (m, 3H, $\left.\mathrm{CH}_{2}=\mathrm{CH}-\right), 4.83 \mathrm{ppm}(\mathrm{Br}, 1 \mathrm{H},-\mathrm{N} H-\mathrm{COO}-), 4.23 \mathrm{ppm}(\mathrm{t}, 2 \mathrm{H}$, $\left.-\mathrm{COOCH}_{2} \mathrm{CH}_{2} \mathrm{NH}-\right), 3.44$ ppm (t, $\left.2 \mathrm{H}, \quad-\mathrm{COOCH}_{2} \mathrm{CH}_{2} \mathrm{NH}-\right), 1.46$ ppm $\quad(\mathrm{s}, 9 \mathrm{H}$, $\left.-\mathrm{COOC}\left(\mathrm{CH}_{3}\right)_{3}\right)$.

\section{Synthesis of 1,1,1-Tri(2'-bromo-2'-methylpropionyloxymethyl)propane (TBMP).}

1,1,1-tri(hydroxymethyl) propane $(4.0 \mathrm{~g}, 30 \mathrm{mmol})$ was dissolved in $\mathrm{CHCl}_{3}$ (100 $\mathrm{mL})$ followed by addition of triethyl amine $(9.2 \mathrm{~g}, 90 \mathrm{mmol})$. The resulting mixture was then cooled with an ice/water bath, followed by addition of 2-bromoisobutyryl bromide $(24.8 \mathrm{~g}, 108 \mathrm{mmol})$ in $\mathrm{CHCl}_{3}(40 \mathrm{~mL})$ in dropwise (this step takes $\sim 30 \mathrm{~min}$ ). After having been stirred at room temperature for overnight, the resulting mixture was filtered and subsequently washed with DI water for three times $(30 \mathrm{~mL}$ each time). The residual organic phase was dried with anhydrous $\mathrm{MgSO}_{4}$, subjected to rotary evaporation at reduced pressure, and purified with silica gel-column chromatography with hexane/ethyl acetate $(1: 2, \mathrm{v} / \mathrm{v})$ as the eluant, which yielded TBMP as white solid. ${ }^{1} \mathrm{H}$ NMR spectrum (AC-250, Bruker) (Figure S2) confirmed the successful preparation of TBMP. ${ }^{1} \mathrm{H} \mathrm{NMR}\left(\mathrm{CDCl}_{3}, \mathrm{ppm}\right): \delta 4.18 \mathrm{ppm}\left(\mathrm{s}, 6 \mathrm{H},-\mathrm{C}-\left(\mathrm{CH}_{2}-\mathrm{O}-\right)_{3}\right)$, 1.93 ppm (s, 18H, -C- $\left.\left(\mathrm{CH}_{3}\right)_{2}-\mathrm{Br}\right), 1.62 \mathrm{ppm}\left(\mathrm{f}, 2 \mathrm{H}, \mathrm{CH}_{3}-\mathrm{CH}_{2}-\mathrm{C}-\right), 0.97$ (t, 3H, $\left.\mathrm{CH}_{3}-\mathrm{CH}_{2}-\mathrm{C}-\right)$. 


\section{Synthesis of propargyl 2,2-bis(2'-bromo-2'-methylpropanoyloxy)methyl propionate (PBP).}

Propargyl 2,2-bis(2'-bromo-2'-methylpropanoyloxy)methyl propionate (PBP) was synthesized with a previously reported procedure (Scheme S2) ${ }^{12}$.

\section{Synthesis of Isopropylidene-2,2-bis(methoxy)propionic Acid (product I).} 2,2-Bis(hydroxymethyl) propionic acid (14.1 g, $100 \mathrm{mmol}$ ), 2,2-dimethoxypropane (20.0 $\mathrm{mL}, 168.4 \mathrm{mmol})$, and $p$-toluenesulfonic acid monohydrate (1 g, $5.5 \mathrm{mmol})$ were dissolved in acetone $(100 \mathrm{~mL})$. The mixture was stirred for $4 \mathrm{~h}$ at room temperature, followed by addition of a mixture $(2.0 \mathrm{~mL})$ of an ammonia solution $(25 \%)$ and $\mathrm{EtOH}(50 / 50, \mathrm{v} / \mathrm{v}))$ to neutralize the catalyst. The solvent was removed via evaporation under reduced pressure at room temperature, and the residue was dissolved in $\mathrm{CH}_{2} \mathrm{Cl}_{2}(200 \mathrm{~mL})$ and extracted with two portions of water (30 mL each). The organic phase was dried with anhydrous $\mathrm{MgSO}_{4}$ and evaporated to give isopropylidene-2,2-bis(methoxy)- propionic acid (product I) as white powder with a yield of $66 \%$. The ${ }^{1} \mathrm{H}-\mathrm{NMR}$ spectra were recorded using a NMR spectrometer commercial (AV400, Bruker), and ${ }^{1} \mathrm{H} \mathrm{NMR}\left(\mathrm{CDCl}_{3}, \mathrm{ppm}\right):{ }^{1} \mathrm{H} \mathrm{NMR}\left(\mathrm{CDCl}_{3}, \mathrm{ppm}\right)$ : $\delta 4.18\left(\mathrm{~d}, 2 \mathrm{H},-\mathrm{CH}_{2} \mathrm{O}\left(\mathrm{CH}_{3}\right) \mathrm{C}\left(\mathrm{CH}_{3}\right) \mathrm{OCH}_{2}-\right), 3.65\left(\mathrm{~d}, 2 \mathrm{H},-\mathrm{CH}_{2} \mathrm{O}\left(\mathrm{CH}_{3}\right) \mathrm{C}-\left(\mathrm{CH}_{3}\right) \mathrm{OCH}_{2}-\right)$, 1.41(s, 3H, $\left.-\mathrm{CH}_{2} \mathrm{O}-\left(\mathrm{CH}_{3}\right) \mathrm{C}\left(\mathrm{CH}_{3}\right) \mathrm{OCH}_{2}-\right), 1.38\left(\mathrm{~s}, 3 \mathrm{H},-\mathrm{CH}_{2} \mathrm{O}\left(\mathrm{CH}_{3}\right) \mathrm{C}\left(\mathrm{CH}_{3}\right)-\mathrm{OCH}_{2}-\right)$, $1.20\left(\mathrm{~s}, 3 \mathrm{H}, \mathrm{CH}_{3} \mathrm{C}\left(\mathrm{CH}_{2} \mathrm{O}-\right)_{2} \mathrm{COOH}\right)$

Propargyl 2,2,5-Trimethyl-1,3-dioxane-5-carboxylate (product II). Propargyl alcohol (5.7 mL, $98.8 \mathrm{mmol})$, isopropylidene-2,2-bis(methoxy)- propionic acid (I) (11.5 g, $66 \mathrm{mmol}$ ), and DMAP (3.94 g, $32.4 \mathrm{mmol})$ was dissolved in $\mathrm{CH}_{2} \mathrm{Cl}_{2}(300$ 
$\mathrm{mL}$ ). The resulting mixture was stirred at room temperature for $10 \mathrm{~min}$, followed by drop-wise addition of the solution of DCC (42 g, $204 \mathrm{mmol})$ in $\mathrm{CH}_{2} \mathrm{Cl}_{2}(100 \mathrm{~mL})$ under $\mathrm{N}_{2}$ flow (the addition should be completed within $30 \mathrm{~min}$ ). The resulting mixture was stirred overnight at room temperature, and urea byproduct was removed via filtration. The resulting solution was diluted with $\mathrm{CH}_{2} \mathrm{Cl}_{2}(300 \mathrm{~mL})$ and extracted with two portions of water $(50 \mathrm{~mL}$ each), and the organic phase was dried with anhydrous $\mathrm{MgSO}_{4}$. The solvent was evaporated, and the residue was purified by silica-gel column chromatography using hexane/ethyl acetate $(25: 1, \mathrm{v} / \mathrm{v})$ as eluant, which yielded product II as colorless clear oil with a yield of $69 \%$. ${ }^{1} \mathrm{H}-\mathrm{NMR}$ $\left(\mathrm{CDCl}_{3}, \mathrm{ppm}\right): \delta 4.74\left(\mathrm{~d}, 2 \mathrm{H}, \mathrm{CH} \equiv \mathrm{CCH}_{2} \mathrm{O}-\right), 4.20\left(\mathrm{~d}, 2 \mathrm{H},-\mathrm{CH}_{2} \mathrm{O}\left(\mathrm{CH}_{3}\right) \mathrm{C}\left(\mathrm{CH}_{3}\right) \mathrm{OCH}_{2}-\right)$, $3.67\left(\mathrm{~d}, 2 \mathrm{H},-\mathrm{CH}_{2} \mathrm{O}\left(\mathrm{CH}_{3}\right) \mathrm{C}\left(\mathrm{CH}_{3}\right) \mathrm{OCH}_{2}-\right), 2.48\left(\mathrm{t}, 1 \mathrm{H}, \mathrm{CH} \equiv \mathrm{CCH}_{2} \mathrm{O}-\right), 1.43(\mathrm{~s}, 3 \mathrm{H}$, $\left.-\mathrm{CH}_{2} \mathrm{O}\left(\mathrm{CH}_{3}\right) \mathrm{C}\left(\mathrm{CH}_{3}\right) \mathrm{OCH}_{2}-\right), 1.39\left(\mathrm{~s}, 3 \mathrm{H},-\mathrm{CH}_{2} \mathrm{O}-\left(\mathrm{CH}_{3}\right) \mathrm{C}\left(\mathrm{CH}_{3}\right) \mathrm{O}-\mathrm{CH}_{2}-\right), 1.22(\mathrm{~s}, 3 \mathrm{H}$, $\left.\mathrm{CH}_{3} \mathrm{C}\left(\mathrm{CH}_{2} \mathrm{O}-\right)_{2} \mathrm{COOH}\right)$.

\section{Propargyl 3-Hydroxy-2-(hydroxymethyl)-2-methylpropanoate (product III).}

Propargyl 2,2,5-trimethyl-1,3-dioxane-5-carboxylate (II) (5.2 g, $23.6 \mathrm{mmol})$ was dissolved in a mixture of $\mathrm{HCl}(1 \mathrm{M}, 10 \mathrm{~mL})$ and $\mathrm{THF}(10 \mathrm{~mL})$. The resulting mixture was stirred for $4 \mathrm{~h}$ at room temperature. The precipitates were removed via filtration, and the resulting solution was subsequently diluted by $\mathrm{CH}_{2} \mathrm{Cl}_{2}(200 \mathrm{~mL})$ and extracted with two portions of water $(30 \mathrm{~mL}$ each). The resulting organic phase was dried with anhydrous $\mathrm{MgSO}_{4}$ and concentrated via evaporation at reduced pressure, followed by addition of hexane $(5 \mathrm{~mL})$ and storage in freezer for $48 \mathrm{~h}$ to give product III as white solid with a yield of $90 \% .{ }^{1} \mathrm{H}-\mathrm{NMR}\left(\mathrm{CDCl}_{3}, \mathrm{ppm}\right): 4.77$ (d, 
$\left.2 \mathrm{H}, \mathrm{CH} \equiv \mathrm{CCH}_{2} \mathrm{O}-\right), 3.93\left(\mathrm{~d}, 2 \mathrm{H},-\mathrm{CH}_{2} \mathrm{OH}\right), 3.74\left(\mathrm{~d}, 2 \mathrm{H},-\mathrm{CH}_{2} \mathrm{OH}\right), 2.73(\mathrm{br}, 2 \mathrm{H},-\mathrm{OH})$, $2.50\left(\mathrm{t}, 1 \mathrm{H}, \mathrm{CH} \equiv \mathrm{CCH}_{2} \mathrm{O}-\right), 1.10\left(\mathrm{~s}, 3 \mathrm{H},-\mathrm{CH}_{3}\right)$.

\section{Propargyl 2,2-Bis((20-bromo-20-methylpropanoyloxy)methyl)propionate}

(product IV). Propargyl 3-hydroxy-2-(hydroxymethyl)-2-methylpropanoate (2.1 g, $13.0 \mathrm{mmol})$ was dissolved in $\mathrm{CH}_{2} \mathrm{Cl}_{2}(90 \mathrm{~mL})$, followed by addition of triethyl amine $(4.0 \mathrm{~mL}, 28.5 \mathrm{mmol})$. The resulting mixture was cooled to $0{ }^{\circ} \mathrm{C}$ in a ice/water bath, followed by drop-wise addition of the solution of 2-bromoisobutryl bromide (6.05 g, $26.0 \mathrm{mmol})$ in $\mathrm{CH}_{2} \mathrm{Cl}_{2}(40 \mathrm{~mL})$ (the addition should be completed within 30 min). The resulting mixture was stirred at room temperature overnight. The precipitates were removed via filtration, and the resulting solution was extracted successively with $\mathrm{CH}_{2} \mathrm{Cl}_{2}(200 \mathrm{~mL})$ and saturated aqueous solution of $\mathrm{NaHCO}_{3}(200$ $\mathrm{mL})$. The resulting aqueous phase was subsequently extracted with $\mathrm{CH}_{2} \mathrm{Cl}_{2}(100 \mathrm{~mL})$, and the resulting organic phase was dried with anhydrous $\mathrm{MgSO} 4$, concentrated via evaporation at reduced pressure, and subsequently eluted through a silica-gel column chromatography using hexane/ethyl acetate $(4: 1, \mathrm{v} / \mathrm{v})$ as eluant, which gave PBP as white crystal with a yield of $87 \% . \quad{ }^{1} \mathrm{H}$ NMR spectrum (AC-250, Bruker) (Figure S3) confirmed the successful preparation of PBP. ${ }^{1} \mathrm{H}-\mathrm{NMR}\left(\mathrm{CDCl}_{3}, \mathrm{ppm}\right): \delta 4.74(\mathrm{~d}, 2 \mathrm{H}$, $\left.\mathrm{CH} \equiv \mathrm{CCH}_{2} \mathrm{O}-\right), 4.37\left(\mathrm{~m}, 4 \mathrm{H},-\mathrm{COOCH}_{2}-\right), 2.47\left(\mathrm{t}, 1 \mathrm{H}, \mathrm{CH} \equiv \mathrm{CCH}_{2} \mathrm{O}-\right), 1.92(\mathrm{~s}, 12 \mathrm{H}$, $\left.-\mathrm{CBr}\left(\mathrm{CH}_{3}\right)_{2}\right), 1.37\left(\mathrm{~s}, 3 \mathrm{H},-\mathrm{CH}_{3}\right)$.

\section{Synthesis of $M_{6}$ TREN}

Me6TREN were synthesized with a previously reported procedure ${ }^{13}$. Synthesis of trenMe- $\left[\mathrm{N}\left(\mathrm{CH}_{2} \mathrm{CH}_{2} \mathrm{NH}_{3}\right) \mathrm{Cl}_{3}\right]$ was prepared Ristempart's synthesis with slight 
modification. A mixture of this hydrochloride $(10 \mathrm{~g})$, water $(5 \mathrm{~mL})$,. aqueous solution of formic acid $(85 \%, \mathrm{v} / \mathrm{v}, 40 \mathrm{~mL})$, and aqueous solution of formaldehyde $(30 \%, \mathrm{v} / \mathrm{v}, 30 \mathrm{~mL})$ was heated at $120^{\circ} \mathrm{C}$ until the evolution of carbon dioxide had practically stopped (ca. $6 \mathrm{hr}$.). All the volatile fractions were then removed by vacuum distillation. The solid residue was treated with aqueous solution of sodium hydroxide $(10 \%, 200 \mathrm{~mL})$, and the resulting oily layer was extracted into ethyl ether (200 mL). The resulting ethereal extract was dried over anhydrous potassium hydroxide and then subjected successively evaporation at reduced pressure and distillation (to remove ethyl ether), which yielded the tris(2-dimethylaminoethyl) amine as a colorless oil with a yield of 91\%. 1H-NMR $\left(\mathrm{CDCl}_{3}, \mathrm{ppm}\right): \delta 2.70(\mathrm{t}, 6 \mathrm{H}$, $\left.\mathrm{N}-\left(\mathrm{CH}_{2} \mathrm{CH}_{2} \mathrm{~N}-\left(\mathrm{CH}_{3}\right)_{2}\right)_{3}\right), \quad 2.47 \quad\left(\mathrm{t}, \quad 2 \mathrm{H}, \quad \mathrm{N}-\left(\mathrm{CH}_{2} \mathrm{CH}_{2} \mathrm{~N}-\left(\mathrm{CH}_{3}\right)_{2}\right)_{3}\right), \quad 2.31 \quad(\mathrm{~s}$, $\left.\mathrm{N}-\left(\mathrm{CH}_{2} \mathrm{CH}_{2} \mathrm{~N}-\left(\mathrm{CH}_{3}\right)_{2}\right)_{3}\right)$.

\section{Synthesis of G2-Boc}

G2-Boc was synthesized with a divergent synthetic strategy via SET-LRP of AEA-Boc (Scheme S1). Briefly, tri-arm star PAEA-Boc (G0-Boc) was synthesized from the tri-functional initiator TBMP via SET-LRP. From G0-Boc, the first generation of Boc-protected $l c d$-PAEA precursor dendrimer (G1-Boc) was synthesized by converting the terminal bromo groups of $\mathrm{G} 0$-Boc into azido groups with $\mathrm{NaN}_{3}$ in $\mathrm{DMF}$ and subsequently introducing the bifunctional initiating PBP molecules to the ends (which yielded (G0-Boc)-ini), followed by SET-LRP of AEA-Boc through alkynyl-azido click reaction; with a similar procedure, G2-Boc was prepared from G1-Boc. 


\section{Synthesis of G0-Boc}

Into a round-bottom glass ampoule with a magnetic stirring bar was added TBMP (0.117 g, $0.2 \mathrm{mmol})$, Boc-AEA (4.8 g, $22.3 \mathrm{mmol}), \mathrm{Me}_{6} \mathrm{TREN}$ (34 mg, $0.15 \mathrm{mmol}$ ), and isopropanol $(25 \mathrm{~mL})$. The resultant mixture was subsequently degassed via three freeze-pump-thaw cycles, followed by addition of $\mathrm{CuBr}(21.6 \mathrm{mg}, 0.15 \mathrm{mmol})$. The ampoule was then sealed under vacuum with flame, heated in an oil bath at $30{ }^{\circ} \mathrm{C}$ for $1.5 \mathrm{~h}$, immersed into liquid nitrogen to freeze the mixture therein and consequently quench the reaction, opened via breaking its neck for oxidization in air for $30 \mathrm{~min}$. The resulting mixture diluted with tetrahydrofuran (THF), eluted through a short neutral-alumina column with THF as the eluant to remove the metal salt, and then subjected to rotary evaporation at reduced pressure to remove the solvent. The oily residue was dissolved with $\mathrm{THF}$, and the resulting mixture was added into excessive amount of hexane, which raw yieled G0-Boc as oily precipitates; to futher remove monomers co-aggregated with the product, this precipitation was repeated for three times. The resulting product was dried under vacuum at room temperature for overnight, which yielded purified G0-Boc with an yield of $40 \%$.

\section{Synthesis of G1-Boc.}

G0-Boc (1.6 g, $0.17 \mathrm{mmol})$ was dissolved in N,N-Dimethylformamide (DMF, 40 $\mathrm{mL})$ followed by addition of $\mathrm{NaN}_{3}(0.6 \mathrm{~g}, 5 \mathrm{mmol})$. The resulting mixture was stirred at room temperature for $48 \mathrm{~h}$, diluted with $\mathrm{THF}$, eluted through a neutral-alumina column with THF as the eluant, and then subjected to evaporation at reduced pressure to remove the solvent. The oily residue was dissolved with THF, and the resulting 
mixture was added into excessive amount of hexane, which yielded crude (G0-Boc)- $\mathrm{N}_{3}$ as oily precipitates; to futher purify the product, this precipitation was repeated for three times. The resulting product was dried under vacuum at room temperature for overnight, whiched yielded purified (G0-Boc)- $\mathrm{N}_{3}$ with an yield of 67 $\%$.

Into a round-bottom glass ampoule with a magnetic stirring bar was added PBP (2.8 g, $0.368 \mathrm{mmol})$, PMDETA (102.0 $\mathrm{mg}, 0.590 \mathrm{mmol})$ and DMF $(25 \mathrm{~mL})$. The resultant mixture was subsequently degassed via three freeze-pump-thaw cycles, followed by addition of $\mathrm{CuBr}(87 \mathrm{mg}, 0.610 \mathrm{mmol})$. The ampoule was then sealed under vacuum with flame, heated with a oil-bath at $35{ }^{\circ} \mathrm{C}$ for $3 \mathrm{~h}$, immersed into liquid nitrogen to freeze the mixture therein and consequently quench the reaction, and opened via breaking its neck for oxidization in air for $30 \mathrm{~min}$. The resulting mixture was thendiluted with THF, eluted through a short neutral-alumina column, and subjected to evaporation at reduced pressure to remove the solvent. The oily residue was dissolved with $\mathrm{THF}$, and the resulting mixture was added into excessive amount of hexane, which yielded crude (G0-Boc)-ini as oily precipitates; to futher purify the product, this precipitation was repeated for three times. The resulting product was dried under vacuum at room temperature for overnight, which yielded purified (G0-Boc)-ini as transparent solid with an yield of $70 \%$.

Into a round-bottom ampoule with a stirring bar was added (G0-Boc)-ini (1.2 g, $0.210 \mathrm{mmol}$ ), AEA-Boc (8.0 g, $210.0 \mathrm{mmol}), \mathrm{Me}_{6}$ TREN (46 mg, $0.192 \mathrm{mmol}$ ) and isopropanol $(35 \mathrm{~mL})$. The resulting mixture was degassed via three 
freeze-pump-thaw cycles followed by addition of $\mathrm{CuBr}(28 \mathrm{mg}, 0.194 \mathrm{mmol})$. The ampoule was consequently sealed under vacuum with flame, heated in an oil bath at $30{ }^{\circ} \mathrm{C}$ for $1.5 \mathrm{~h}$. immersed into liquid nitrogen to freeze the mixture therein and quench the reaction, opened for oxidation in air for $30 \mathrm{~min}$. The resulting mixture was diluted with THF and eluted through a short neutral-alumina column, and subjected to rotary evaporation at reduced pressure to remove the solvent. The oily residue was dissolved with THF, and the resulting mixture was added into excessive amount of hexane, which yielded crude G1-Boc as oily precipitates; to futher purify the product, this precipitation was repeated for three times. The resulting product was dried under vacuum at room temperature for overnight, which yielded purified G1-Boc as transparent solid with an yield of $36 \%$.

\section{Synthesis of G2-Boc.}

G2-Boc was prepared from G1-Boc with a similar procedure as for preparing G1-Boc but with slight modifition on the purification procedure. To purify G2-Boc, crude G2-Boc (2.0 g) obtained after rotory evaporation was dissolved with actone (60 $\mathrm{mL}$ ) followed by addition of hexane in drop-wise till the resulting mixture appeared like an emulsion. The resulting mixture was subsequently heated in a water bath at $50{ }^{\circ} \mathrm{C}$ until it appeared to be clear and transported into a fractional bottom kept in a water bath at $50{ }^{\circ} \mathrm{C}$. The temperature of the water bath was then decreased by $2{ }^{\circ} \mathrm{C}$ each day since then till phase separation occurred in the fractional bottom. The resulting concentrated phase was collected and then precipitated into the hexane as 
described above, leading to oily precipitates which, after being dried under vacuum at room temperature for overnight, yielded purified G2-Boc as uncolored solid.

\section{Synthesis of G0, G1, and G2.}

G0, G1, and G2 were prepared by subjecting G0-Boc, G1-Boc, and G2-Boc, respectively, to TFA-deprotection. Briefly, Gn-Boc $(\mathrm{n}=0$, 1, or $2 ; 2.0 \mathrm{~g})$, was hydrolyzed in trifluoroacetic acid (TFA, $6 \mathrm{~mL}$ ) at room temperature for $4 \mathrm{~h}$, and the resulting mixture was dialyzed against DI water until $\mathrm{pH}$ of the dialysate reached 7.0, followed by lyophilization to yield the corresponding $\mathrm{Gn}(\mathrm{n}=0,1$, or 2$)$ with a yield of $\sim 90 \%$.

\section{Synthesis of alkynyl-(PCL-b-PEG)}

PCL- $b$-PEG was prepared via cationic ring-openning polymerization. Briefly, into a three-necked flask with a stirring bar was added PEG-2000 (4.0 g, 2 mmol), $\mathrm{Sn}(\mathrm{Oct})_{2}(0.16 \mathrm{~g}, 0.4 \mathrm{mmol})$, and toluene $(40 \mathrm{~mL})$, followed by addition of E-caprolactone $(6.84 \mathrm{~g}, 60 \mathrm{mmol})$ under $\mathrm{N}_{2}$ flow. The resulting mixture was kept in an oil bath at $100{ }^{\circ} \mathrm{C}$ for $5 \mathrm{~h}$. The solvent was then removed by a rotary evaporator, and the oily residue was dissolved with THF which, after precitation with excessive amount of ice-cold ethyl ether for three times and dehydration under vacuum at $60{ }^{\circ} \mathrm{C}$ for overnight, yielded purified PCL- $b$-PEG as light-yellow powder with yield of $87 \%$.

Alkynyl-(PCL- $b$-PEG), PCL- $b$-PEG with an alkynyl end functional group, was synthesized via procedure described as following. PCL- $b$-PEG (4.0 g, $0.8 \mathrm{mmol})$, 
propiolic acid (0.56 g, $8 \mathrm{mmol})$ and DMAP (9.76 $\mathrm{mg}, 0.08 \mathrm{mmol})$ were dissolved with $\mathrm{CH}_{2} \mathrm{Cl}_{2}(150 \mathrm{~mL})$. The resulting mixture was stirred at room temperature for 10 min, added with DCC (1.65 $\mathrm{g}, 8 \mathrm{mmol})$ in $\mathrm{CH}_{2} \mathrm{Cl}_{2}(20 \mathrm{~mL})$ in drop-wise (completed within $10 \mathrm{~min}$ ), stirred for overnight, and filtered. The filtrated mixture was then subjected to rotary evaporation under reduced pressure to remove solvent, and the orange residue was diluted with THF followed by precipitation in excessive amount of ethyl ether for three times, which yielded purified alkynyl-(PCL-b-PEG) as orange solid with a yield of $90 \%$. Both ${ }^{1} \mathrm{H}-\mathrm{NMR}$ spectrum (AC-250, Bruker) (Figure S10) confirmed the successful preparation of alkynyl-(PCL- $b$-PEG) and, based on the ${ }^{1} \mathrm{H}-\mathrm{NMR}$ spectrum, the number-averaged degree of polymerization for the PCL block, $n_{\mathrm{PCL}}$, was estimated to be 25$)$.

\section{Synthesis of G2-g-(PCL-b-PEG)}

The preparation of G2-g-(PCL- $b$-PEG) comprises two steps (Scheme S1): synthesizing G2-Boc, and preparing G2-g-(PCL- $b$-PEG) by PEGylating G2-Boc with PCL- $b$-PEG via CuAAc click chemistry followed by TFA-deprotection. G2-Boc (3 g, $0.05 \mathrm{mmol})$ was dissolved in DMF $(40 \mathrm{~mL})$ followed by addition of $\mathrm{NaN}_{3}(0.6 \mathrm{~g}, 5$ mmol). The resulting mixture was stirred at room temperature for $48 \mathrm{~h}$, diluted with THF, eluted through a neutral-alumina column with THF as the eluant, and then subjected to evaporation under reduced pressure to remove the solvent. The oily residue was diluted with THF, and the resulting mixture was added into excessive amount of hexane, which yielded crude (G2-Boc) $-\mathrm{N}_{3}$ as oily precipitates; to futher purify the product, this precipitation was repeated for three times. The resulting 
product was dried under vacuum at room temperature for overnight, which yielded purified (G2-Boc)- $\mathrm{N}_{3}$ as transparent solid with an yield of $61 \%$.

(G2-Boc)-g-(PCL- $b$-PEG) was synthesized with a procedure described as following. Into a glass ampoule with a stirring bar were added alkynyl-PCL- $b$-PEG (1.5 g, 0.03 mmol), (G2-Boc)-N $3(1.5 \mathrm{~g}, 0.025 \mathrm{mmol})$, PMDETA (4.3 mg, $0.025 \mathrm{mmol})$ and DMF $(15 \mathrm{~mL})$. The resulting mixture was degassed via three freeze-pump-thaw cycles followed by addition of $\mathrm{CuBr}(3.6 \mathrm{mg}, 0.025 \mathrm{mmol})$. The ampoule was sealed under vacuum with flame, kept in an oil bath at $35{ }^{\circ} \mathrm{C}$ for $3 \mathrm{~h}$. immersed into liquid nitrogen till the mixture therein freezed, and opened for oxidation in air for $30 \mathrm{~min}$. The as-oxidized mixture was subsequently diluted with THF, eluted through a short neutral-alumina column with THF as the eluant, followed by rotary evaporation under reduced pressure to remove solvent. The residue (light-yellow solid) was dissolved in THF, precipited in excessive amount of hexane for three times, and then dried under vacuum overnight. The resultant light-yellow solid was purified (G2-Boc)-g-(PCL- $b$-PEG) which. after $\quad$ TFA-deprotection $\quad(2.0 \quad \mathrm{~g}$ (G2-Boc)-g-(PCL-b-PEG)) in $10 \mathrm{~mL}$ TFA at room temperature for $4 \mathrm{~h}$ followed successively by dialysis and lyophilization), yielded purified G2- $g$-(PCL- $b$-PEG) as light-yellow solid (yield: $88 \%$ ).

\section{Structural characterizations on the products}

Proton nuclear magnetic resonance $\left({ }^{1} \mathrm{H}-\mathrm{NMR}\right)$ characterizations were conducted with a NMR spectrometer (Bruker AC-250) in $\mathrm{CDCl}_{3}, \mathrm{D}_{2} \mathrm{O}$, or $d^{6}$-DMSO at $25^{\circ} \mathrm{C}$. 
Fourier transform infrared spectroscopy (FT-IR) characterizations were performed with an FT-IR spectrometer (Equinox $55 / \mathrm{s}$, Bruker) at $25^{\circ} \mathrm{C}$ in $\mathrm{KBr}$ pellets.

\section{Gel permeation chromatography characterizations}

Gel permeation chromatography (GPC) traces were monitored with a GPC system (Waters 1515) equipped with three Styragel columns (HR2, HR4, HR6) and a differential refractive index (RI) detector at $35{ }^{\circ} \mathrm{C}$ using polystyrene (PS) standard for the calibration and THF as the eluent at $1 \mathrm{~mL} / \mathrm{min}$, which indicate the apparent molecular weights $\left(M_{\mathrm{n}, \mathrm{GPC}}\right.$ and $\left.M_{\mathrm{w}, \mathrm{GPC}}\right)$ and polydispersity index (PDI = $\left.M_{\mathrm{w}, \mathrm{GPC}} / M_{n, \mathrm{GPC}}\right)$.

GPC-MALLS characterizations were carried out to obtain the absolute molecular weight, $M_{\mathrm{w}, \mathrm{MALLS}}$, using the same GPC system but a multiangle laser light scattering (MALLS) as the detector (Wyatt Dawneos) followed by data analysis with ASTRA software for Windows (Ver. 4.90.07, Wyatt). The differential refractive index, $\mathrm{d} n / \mathrm{d} C$, was measured via a procedure previously reported ${ }^{14}$, and its value for PAEA-Boc in THF was determined to be $0.134 \mathrm{~mL} / \mathrm{g}$ at $30{ }^{\circ} \mathrm{C}$.

\section{Product size characterizations}

The hydrodynamic radius $\left(R_{\mathrm{h}}\right)$ and the gyration radius $\left(R_{\mathrm{g}}\right)$ of the as-prepared products were characterized using a commercial laser light scattering spectrometer (DLS/SLS-5022F, ALV) equipped with an ALV-5000 multi- $\tau$ digital time correlator and a cylindrical $22 \mathrm{~mW}$ Uniphase He-Ne laser $\left(\lambda_{0}=632.8 \mathrm{~nm}\right)$.

Static laser light scattering measurements were carried out at $25^{\circ} \mathrm{C}$, by monitoring the scattering intensity at scatter angles ranging from $20^{\circ}$ to $150^{\circ}$ with step-sizes of $2^{\circ}$ 
for $20-50^{\circ}$ and $5^{\circ}$ for $50-150^{\circ}$, respectively; the scattering intensity at each scattering angle was recorded for three times and, for each time, averaged over $10 \mathrm{~s}$.

Dynamic laser light scattering measurements were performed at $25{ }^{\circ} \mathrm{C}$ unless specified otherwise, by monitoring the incident and scattering intensities at a fixed scattering angle of $30^{\circ}$ for over $10 \mathrm{~min}$, which after the CONTIN analysis and cumulant expansion analysis indicate the time correlation functions.

\section{Product zeta-potential ( $\zeta$-potential) characterizations}

Zeta-potentials of G2 and G2-g-(PCL- $b$-PEG) in HEPES buffer solution were measured using a Zetasizer (Nano-ZS, Malvern) at room temperature, with an incidence light and a scattering angle of $632.8 \mathrm{~nm}$ and $173^{\circ}$, respectively. The polycation core content in the G2-g-(PCL-b-PEG) sample was kept the same as that in G2 sample, both of which were set to be $0.1 \mathrm{mg} / \mathrm{mL}$.

\section{Colloidal stability of G2-g-(PCL-b-PEG) and G2}

The colloidal stability of G2-g-(PCL- $b$-PEG) $(128 \mu \mathrm{g} / \mathrm{mL})$ and G2 $(64 \mu \mathrm{g} / \mathrm{mL})$ were assessed by monitoring their hydrodynamic radii in HEPES buffer supplemented with fetal bovine serum (FBS) $(50 \%, \mathrm{v} / \mathrm{v})$ at $37{ }^{\circ} \mathrm{C}$ over a span of 5 days, using a procedure as described above.

\section{Bacterial lipase-induced degradation of G2-g-(PCL-b-PEG) by lipase}

G2-g-(PCL- $b$-PEG) was dissolved in HEPES buffer solution to a concentration of 1 $\mathrm{mg} / \mathrm{mL}$, followed by addition of Burkholderiacepacia lipase in HEPES solution (concentration and volume). Immediately after that, the resulting mixture was 
sterilized with a filter (PVDF pore-size of $0.22 \mu \mathrm{m}$, Millpore) and subsequently subjected to DLS measurement at $37^{\circ} \mathrm{C}$.

\section{Bacterial plate killing assays.}

Plate bacterial killing assays were used to bactericidal activity evaluation. For each bacterial strain, several individual colonies were inoculated into fresh tryptic soy broth (TSB) and incubated at $37^{\circ} \mathrm{C}$ for $18 \mathrm{~h}$ to stationary phase. A $40 \mu \mathrm{L}$ culture was diluted with fresh TSB $(4 \mathrm{~mL})$ and regrown at $37{ }^{\circ} \mathrm{C}$ to mid log phase $(\mathrm{OD} 600=$ 0.5-0.7). Bacterial cells were washed twice with sterile 2-[4-(2-hydroxyethyl)-1-piperazinyl]ethanesulfonic acid (HEPES) buffer (10 mM HEPES, $150 \mathrm{mM} \mathrm{NaCl}, \mathrm{pH}$ 7.4) via centrifugation (10000 rpm for S.aureus and 5000 rcf for other bacterial strains) for $5 \mathrm{~min}$. Within $15 \mathrm{~min}$, bacterial cells were adjusted with sterile HEPES burrer to $\sim 1.5 \times 10^{6} \mathrm{CFU} / \mathrm{mL}$ inoculated into zero-dilution wells of a preset 96-well microplate.

Serial 2-fold dilutions of lcd-PAEA solutions in Millipore water were made with HEPES buffer. Each antimicrobial dilution $(20 \mu \mathrm{L})$ was added into each zero-dilution well in a 96-well microplate. Adjusted bacteria suspension $(50 \mu \mathrm{L})$ was introduced into each zero-dilution well of a preset microplate, to achieve $5 \times 10^{5} \mathrm{CFU} / \mathrm{mL}$ in each well $(150 \mu \mathrm{L})$. The microplate was then incubated at $37{ }^{\circ} \mathrm{C}$ for $3 \mathrm{~h}$. Serial 10 -fold dilutions were made with sterile HEPES buffer subsequently. Each dilution $(20 \mu \mathrm{L})$ was plated onto $\mathrm{MH}$ agar plates, which were then incubated at $37^{\circ} \mathrm{C}$ overnight to give visible colonies. Inoculum size was indicated by control samples containing untreated 
bacteria. Each trial was performed in triplicate, and the reported results were the averages of two independent trials.

\section{Hemolysis assays.}

The stock solution of a dendrimer, G2 or G2- $g$-(PCL- $b-\mathrm{PEG})$, was prepared in sterile HEPES buffer (10 mM HEPES, $150 \mathrm{mM} \mathrm{NaCl}, \mathrm{pH}=7.4)$ and stored in aliquots at $-20^{\circ} \mathrm{C}$. Serial 2-fold dilutions of a dendrimer stock solution were made with sterile HEPES buffer, which yielded dendrimer solutions for hemolysis assays. Fresh mouse blood $(100 \mu \mathrm{L})$ was washed with sterile HEPES buffer and centrifuged at $800 \mathrm{rcf}$, and the pellet was re-suspended into sterile HEPES buffer to yield the mouse red blood cell (mRBC) stock suspension $\left(\sim 2.5 \times 10^{4}\right.$ cells $\left./ \mu \mathrm{L}\right)$ for hemolysis assays. The mRBC stock suspension $(160 \mu \mathrm{L})$ and diluted dendrimer solution (40 $\mu \mathrm{L}$ ) were added into each centrifuge cups. After the incubation at $37^{\circ} \mathrm{C}$ for $60 \mathrm{~min}$ with shaking at $200 \mathrm{rpm}$, the centrifuge cups were centrifuged at $800 \mathrm{rcf}$ for $5 \mathrm{~min}$, and the supernatant $(50 \mu \mathrm{L})$ of each cup was transferred into a well of a 96-well microplate and diluted with HEPES buffer $(140 \mu \mathrm{L})$. Hemolysis was monitored by measuring the absorbance of the released hemoglobin at optical density at $414 \mathrm{~nm}$, $\mathrm{OD}_{414}$. Controls included mRBC suspension $(160 \mu \mathrm{L})$ with HEPES buffer $(40 \mu \mathrm{L})$ and mRBC suspension $(160 \mu \mathrm{L})$ treated with triton $\mathrm{X}-100(50 \%, 40 \mu \mathrm{L})$ to provide reference for $0 \%$ and $100 \%$ hemolysis, respectively. Each hemolysis assay trial was carried out in triplicate, and the reported results are the averages of two independent trials.

\section{Bacterial Dead/Live viability assays}


To assess whether the dendrimers were capable of permeabilizing bacterial membranes, we carried out the bacterial Dead/Live viability assays by using BacLight Dead/Live bacterial viability kit (Molecular Probes) and examining the staining effects under a fluorescence microscopy (IX81, Olympus) ${ }^{15}$. For each bacterial strain, 3-5 individual colonies were inoculated into fresh TSB (4 mL) and then incubated at $37{ }^{\circ} \mathrm{C}$ for $20 \mathrm{~h}$ to stationary phase. The bacterial cells were harvested via centrifugation at $710 \mathrm{rcf}$ for $2 \mathrm{~min}$ and washed with sterile HEPES buffer (10 mMHEPES, $150 \mathrm{mM} \mathrm{NaCl}, \mathrm{pH}$ 7.4). The bacterial pellet was re-suspended into sterile HEPES buffer supplemented with $0.03 \% \mathrm{TSB}(\mathrm{v} / \mathrm{v})$, to achieve $\sim 10^{9} \mathrm{CFU} / \mathrm{mL}$. Bacterial solution $(90 \mu \mathrm{L})$ and dendrimer stock solution $(10 \mu \mathrm{L})$ were incubated at 37 ${ }^{\circ} \mathrm{C}$ for $3 \mathrm{~h}$, followed by successive additions of aqueous solutions of SYTO-9 (5 $\left.\mu \mathrm{L}\right)$ and propidium iodide $(5 \mu \mathrm{L})$. The resultant mixtures were incubated at $37{ }^{\circ} \mathrm{C}$ in dark for $15 \mathrm{~min}$ and then centrifuged for $2 \mathrm{~min}$ to remove the supernatant. The resulting bacterial pellets were washed with HEPES $(100 \mu \mathrm{L})$ and fixed with $4 \%$ paraformaldehyde solution $(100 \mu \mathrm{L})$. The resultant bacterial suspension $(10 \mu \mathrm{L})$ was transferred onto a cover-slip, air-dried, immersed with mounting oil (10 $\mu \mathrm{L}$, Molecular Probes), and imaged under a fluorescence microscopy (IX81, Olympus) using a $100 \times$ oil-immersion objective lens. SYTO-9 and propidium iodide were characterized by FITC and TRITC filters, respectively. All bacterial cells were stained green whereas those with compromised cytoplasmic membranes were stained red.

\section{Inner membrane permeability assays.}


The inner membrane permeability of $E$. coli ML-35 indicated by $\beta$-galactosidase activity using o-nitrophenyl- $\beta$-D-galactoside (ONPG) as substrate have been employed to assess the membrane destabilization capability of AMPs and polymer SMAMPs. ${ }^{16-20}$ The E. coli ML-35 strain was a kind gift from Professor Andrè J. Ouellette at the University of Southern California. ONPG was purchased from Sigma-Aldrich (Shanghai, China). ML-35 cells were grown in tryptic soy broth (TSB) at $37^{\circ} \mathrm{C}$ for $18 \mathrm{~h}$ to stationary phase. The resulting bacterial culture $(100 \mu \mathrm{L})$ was diluted with fresh TSB by 100 -fold and re-grown at $37{ }^{\circ} \mathrm{C}$ to mid $\log$ growth phase $\left(\mathrm{OD}_{600}=0.5-0.7\right.$, measured using an Eppendorf BioPhotometer $) . \quad$ ML-35 cells at mid log phase were harvested and washed with HEPES buffer (10 mM HEPES, $150 \mathrm{mM} \mathrm{NaCl}, \mathrm{pH}$ 7.4) for three times and re-suspended into HEPES buffer to $\sim 1 \times$ $10^{8} \mathrm{CFU} / \mathrm{mL}$.

The as-adjusted bacterial inoculum $(15 \mu \mathrm{L})$ was inoculated to a well of a 96-well microplate; the final target suspension in a well had $1 \times 10^{7} \mathrm{CFU} / \mathrm{mL}$ ML-35 cells suspended in HEPES buffer (10 mM HEPES, $150 \mathrm{mM} \mathrm{NaCl}, \mathrm{pH} 7.4)$ supplemented with $1 \%$ TSB and $2.5 \mathrm{mM}$ ONPG and dendrimers at expected concentrations. The $\beta$-galactosidase activity was monitored by measuring $\mathrm{OD}_{400}$ at $37^{\circ} \mathrm{C}$ with an interval of $1 \mathrm{~min}$ for $130 \mathrm{~min}$ using a microplate reader (VarioskanFlash, Thermo Scientific), and dendrimer stock solutions were added at time $t$ in-between the 10th and 11th min during an experiment. Blank controls are those assayed similarly but without dendrimer addition, which provide baseline for data analysis. Contribution of blank control was subtracted from raw data, which yielded the $\Delta\left(\mathrm{OD}_{400}\right)$. Each inner 
membrane permeabilization trial was carried out in triplicate, and the reported results are the averages of two independent trials.

\section{REFERENCES}

(1) Kanyika, B. T. N.; Lungu, D.; Mweetwa, A. M.; Kaimoyo, E.; Njung'e, V. M.; Monyo, E. S.; Siambi, M.; He, G. H.; Prakash, C. S.; Zhao, Y. L.; de Villiers, S. M. Identification of Groundnut (Arachis hypogaea) SSR Markers Suitable for Multiple Resistance Traits QTL Mapping in African Germplasm. Electron. J. Biotechn. 2015, $18,61-67$.

(2) Wu, C.; Zuo, J.; Chu, B. Molecular-Weight Distribution of a Branched Epoxy Polymer - 1,4-Butanediol Diglycidyl Ether with Cis-1,2-Cyclohexanedicarboxylic Anhydride. Macromolecules 1989, 22, 633-639.

(3) Antonietti, M.; Bremser, W.; Schmidt, M. Microgels - Model Polymers for the Cross-Linked State. Macromolecules 1990, 23, 3796-3805.

(4) Burchard, W.; Schmidt, M.; Stockmayer, W. H. Information on Polydispersity and Branching from Combined Quasi-Elastic and Integrated Scattering. Macromolecules 1980, 13, 1265-1272.

(5) Xiong, M.-H.; Bao, Y.; Yang, X.-Z.; Wang, Y.-C.; Sun, B.; Wang, J. Lipase-Sensitive Polymeric Triple-Layered Nanogel for "On-Demand" Drug Delivery. J. Am. Chem. Soc. 2012, 134, 4355-4362.

(6) Wu, C.; Jim, T. F.; Gan, Z.; Zhao, Y.; Wang, S. A Heterogeneous Catalytic Kinetics for Enzymatic Biodegradation of Poly(Epsilon-Caprolactone) Nanoparticles in 
Aqueous Solution. Polymer 2000, 41, 3593-3597.

(7) Nie, T.; Zhao, Y.; Xie, Z. W.; Wu, C. Micellar Formation of Poly(caprolactone-block-ethylene oxide-block-caprolactone) and Its Enzymatic Biodegradation in Aqueous Dispersion. Macromolecules 2003, 36, 8825-8829.

(8) Lam, H. F.; Gong, X. J.; Wu, C. Novel Differential Refractometry Study of the Enzymatic Degradation $\quad$ Kinetics of Poly(ethylene oxide)-b-poly(epsilon-caprolactone) Particles Dispersed in Water. J. Phys. Chem B. 2007, 111, 1531-1535.

(9) Kuroda, K.; DeGrado, W. F. Amphiphilic Polymethacrylate Derivatives as Antimicrobial Agents. J. Am. Chem. Soc. 2005, 127, 4128 -4129.

(10) Jiang, Y.; Yang, X.; Zhu, R.; Hu, K.; Lan, W.-W.; Wu, F.; Yang, L. Acid-Activated Antimicrobial Random Copolymers: A Mechanism-Guided Design of Antimicrobial Peptide Mimics. Macromolecules 2013, 46, 3959-3964.

(11) Wei, G.; Liu, X.; Yuan, L.; Ju, X.-J.; Chu, L.-Y.; Yang, L. Lipid Composition Influences the Membrane-Disrupting Activity of Antimicrobial Methacrylate Co-polymers. J. Biomater. Sci. Polym. Ed. 2011, 22, 2041-2061.

(12) Li, L.; He, C.; He, W.; Wu, C. Formation Kinetics and Scaling of "Defect-Free" Hyperbranched Polystyrene Chains with Uniform Subchains Prepared from Seesaw-Type Macromonomers. Macromolecules 2011, 44, 8195-8206.

(13) Ciampoli.M; Nardi, N. 5-Coordinated High-Spin Complexes of Bivalent Cobalt Nickel and Copper with Tris(2-Dimethylaminoethyl)Amine. Inorg. Chem. 1966, 5, $41-44$. 
(14) Wu, C.; Xia, K.-Q. Incorporation of a Differential Refractometer into a Laser Light-Scattering Spectrometer. Rev. Sci. Instrum. 1994, 65, 587.

(15) Yang, X.; Hu, K.; Hu, G.; Shi, D.; Jiang, Y.; Hui, L.; Zhu, R.; Xie, Y.; Yang, L. Long Hydrophilic-and-cationic Polymers: a Different Pathway toward Preferential Activity against Bacterial over Mammalian Membranes. Biomacromolecules 2014, $15,3267-77$.

(16) Weeks, C. S.; Tanabe, H.; Cummings, J. E.; Crampton, S. P.; Sheynis, T.; Jelinek, R.; Vanderlick, T. K.; Cocco, M. J.; Ouellette, A. J. Matrix Metalloproteinase-7 Activation of Mouse Paneth Cell Pro-Alpha-Defensins - SER43 Down Arrow ILE44 Proteolysis Enables Membrane-Disruptive Activity. J. Biol. Chem. 2006, 281, 28932-28942.

(17) Falla, T. J.; Karunaratne, D. N.; Hancock, R. E. W. Mode of Action of the Antimicrobial Peptide Indolicidin. J. Biol. Chem. 1996, 271, 19298-19303.

(18) Lehrer, R. I.; Barton, A.; Daher, K. A.; Harwig, S. S. L.; Ganz, T.; Selsted, M. E. Interaction of Human Defensins with Escherichia-Coli - Mechanism of Bactericidal Activity. J. Clin .Invest. 1989, 84, 553-561.

(19) Skerlavaj, B.; Romeo, D.; Gennaro, R. Rapid Membrane Permeabilization and Inhibition of Vital Functions of Gram-Negative Bacteria by Bactenecins. Infect. Immun. 1990, 58, 3724-3730.

(20) Hu, K.; Schmidt, N. W.; Zhu, R.; Jiang, Y.; Lai, G. H.; Wei, G.; Palermo, E. F.; Kuroda, K.; Wong, G. C. L.; Yang, L. A Critical Evaluation of Random Copolymer Mimesis of Homogeneous Antimicrobial Peptides. Macromolecules 2013, 46, 
1908-1915. 